\title{
Labellum and gynostemium micromorphology in Polystachya (Orchidaceae)
}

\author{
Mytnik Joanna ${ }^{1}$ (1) - Davies L. Kevin ${ }^{2} \cdot$ Narajczyk Magdalena $^{3} \cdot$ Łuszczek Dorota $^{3} \cdot$ Kubiak Joanna $^{1}$. \\ Szlachetko L. Dariusz ${ }^{1}$
}

Received: 3 May 2019 / Accepted: 12 November 2020 / Published online: 30 December 2020

(C) The Author(s) 2020

\begin{abstract}
Polystachya is a large, pantropical orchid genus of 200 species, most of which occur as epiphytes in sub-saharan Africa. The three-lobed labellum of most Polystachya species possesses a fleshy callus and various types of trichomes and papillae. In this paper, we present the results of micromorphological studies on the labellum of 20 species, representing eight of the 13 sections in the genus, using scanning electron microscopy (SEM). Our results show the scale of infrageneric diversity of trichomes and papillae relative to the sampled sections. They also demonstrate the taxonomic value of labellar micromorphology at the sectional level. The study revealed seven types of papillae and five types of trichomes (uni- and multi-cellular) in Polystachya, some of which, are described here for the first time. Clavate trichomes are the most common and are present in $60 \%$ of the species studied. Moniliform trichomes mainly occur in sect. Polystachya and are strongly characteristic of the section. Pseudopollen is formed by fragmentation of moniliform trichomes or the detachment of other trichomes as bicellular units. We provide, for the first time, evidence for the detachment of the terminal cells of capitate trichomes.
\end{abstract}

Keywords Floral micromorphology $\cdot$ Orchidaceae $\cdot$ Polystachya $\cdot$ Taxonomy $\cdot$ Trichomes

\section{Introduction}

Polystachya Hook., in the family Orchidaceae, comprises almost 200 species of pantropical distribution. However, most of these species (93\%) occur in sub-saharan Africa and Madagascar, and on neighbouring islands. Whereas the majority of the species has a more or less restricted

Handling Editor: Ricarda Riina.

Electronic supplementary material The online version of this article (https://doi.org/10.1007/s00606-020-01724-1) contains supplementary material, which is available to authorized users.

Mytnik Joanna

joanna.mytnik@ug.edu.pl

1 Department of Plant Taxonomy and Nature Conservation, University of Gdańsk, Wita Stwosza 59, 80-308 Gdansk, Poland

2 School of Earth and Ocean Sciences, Cardiff University, Main Building, Park Place, Cardiff CF10 3AT, UK

3 Laboratory of Electron Microscopy, Faculty of Biology, University of Gdansk, Wita Stwosza 59, 80-308 Gdansk, Poland distribution, over 80 species are narrow endemics known only from a few populations. The genus is almost entirely epiphytic, although rarely, some species may occur as lithophytes or grow terrestrially. Members of this genus are sympodial, often producing pseudobulbs that vary greatly in form, the inflorescence arising terminally from the apex of mature pseudobulbs. The characteristic feature of Polystachya is the non-resupinate flower resulting in the uppermost position of the labellum and frequently, the partial fusion of the two lateral sepals to the long columnfoot, thus forming a pouch-like mentum at the top of the flower. The last comprehensive taxonomic revision of the genus (Mytnik-Ejsmont 2011) resulted in the recognition of thirteen sections. Apart from the nominal section whose members are pantropical, all sections are confined to Africa and Madagascar, two sections being endemic to Madagascar and the islands of an Indian Ocean (Mytnik-Ejsmont 2011).

Historically, despite their great morphological diversity, the adaxial labellar trichomes of Polystachya have usually been referred to as pseudopollen. The term, used for the first time by Janse (1886), usually referred to farinaceous hairs that often resembled free, powdery pollen-attracting potential insect visitors. We now know, however that in 
Orchidaceae, not all farinaceous putative pseudopollen contains food reserves, and that not all food-hairs are necessarily farinaceous (Vogel 1978; Davies et al. 2013). Furthermore, pseudopollen lacking food reserves still has the capacity to attract pollinators (Vogel 1978; Kjellsson and Rasmussen 1987; Davies et al. 2002; Davies and Turner 2004). Reproductive biology and pollination strategy have been studied for some groups of epidendroids, e.g. Maxillaria (Davies et al. 2004; Davies et al. 2013), Psilochilus (Pansarin and Amaral 2008), Stanhopea (Pansarin and Amaral 2009), Epidendrum (Pansarin and Pansarin 2014), Gomesa (Pansarin et al. 2017), Bulbophyllum (Stpiczyńska et al. 2015, 2018), Catasetinae (Pansarin and Maciel 2017) and Heterotaxis (Krahl et al. 2019). Flowers of Polystachya display a remarkable range of labellar trichomes (Davies et al. 2002, Davies in Kull et al. 2009, Pansarin and Amaral 2006). Typical pseudopollen, as occurs in Maxillaria Ruiz \& Pav., is formed by the fragmentation of uniseriate, moniliform trichomes into rounded, elliptic or lemon-shaped individual component cells. They appear as yellow-white farinaceous powder on the labellum. It is noteworthy, however that in some species of Maxillaria, such hairs do not always contain food material and still attract pollinators (Davies et al. 2013). In Polystachya, moniliform labellar hairs of identical morphology to those of Maxillaria, are known mainly from members of sect. Polystachya. Food-hairs, occurring in most other members of this genus, are uniseriate, one- to four-celled, often with subclavate to clavate terminal cells, or are bristlelike, or fusiform, sometimes tapered at the apex, the cells being much longer than wide (Davies et al. 2002). Pansarin and Amaral (2006) indicated the collection of pseudopollen in two species of Polystachya, P. concreta and P. foliosa (referred to as P. estrellensis in Pansarin and Amaral 2006, though in our opinion, these taxa are consspecific), together with the list of pollinators. The main difference between the two types of labellar trichomes is that food-hairs generally remain intact, whereas pseudopollen is formed by fragmentation of the trichome into individual cells or into short chains of cells. These results are summarised in Table 1. It is significant that flowers producing pseudopollen tend to lack nectar (Van der Pijl and Dodson 1969). According to Davies et al. (2002), the types of trichomes found in Polystachya generally have limited taxonomic value, with the exception of moniliform, pseudopollen-forming trichomes which seem to occur only in a single section, namely, Polystachya sect. Polystachya. The great diversity of labellar hairs found elsewhere in the genus, whether or not they contain food reserves, probably reflects pollinator specificity.

Although nectar is the most common food-reward amongst members of the Orchidaceae (Van der Pijl and Dodson 1969; Arditti 1992; Dressler 1993), it is lacking in Polystachya. Instead, members of this genus produce various types of food-hair (including pseudopollen) (Davies et al. 2002; Pansarin and Amaral 2006) and are mainly pollinated by halictid bees (Halictidae), such as Lasioglossum emirnense, L. nitididorsatum and Dialictus aff. creberrimus (Dodson and Frymire 1961; Dodson 1962; Goss 1977; Dressler 1993; Pettersson and Nilsson 1993), as well as

Table 1 Types of labellar trichomes occurring in Polystachya (after Davies et al. 2002)

\begin{tabular}{|c|c|c|}
\hline Section & Species & Trichome type (number of cells) \\
\hline Calluniflorae Kraenzl & Polystachya woosnami Rendle & Bristle-like (1-4) \\
\hline \multirow[t]{2}{*}{ Caulescentes Kraenzl } & Polystachya bennettiana Rchb.f & Clavate $(2-4)$ \\
\hline & Polystachya caloglossa Rchb.f & Clavate $(2-4)$ \\
\hline \multirow[t]{4}{*}{ Cultriformes Kraenzl } & Polystachya cultriformis (Thouars) Sprengel & Clavate (1-2) \\
\hline & Polystachya cf. cultriformis (Thouars) Sprengel & Clavate (1-2) \\
\hline & Polystachya maculata P.J.Cribb & Clavate $(2-4)$ \\
\hline & Polystachya campyloglossa Rolfe & Cylindrical (1-3) \\
\hline \multirow[t]{5}{*}{ Humiles Summerh } & Polystachya lawrenceana Kraenzl & Clavate (2-4) \\
\hline & Polystachya cf. ottoniana Rchb.f & Clavate $(2-4)$ \\
\hline & Polystachya piersii P. J.Cribb & Clavate (1-2) \\
\hline & Polystachya pubescens (Lindl.) Rchb.f & Bristle-like but with clavate apices (1-3) \\
\hline & Polystachya aff. villosa Rolfe & Clavate (1) \\
\hline \multirow[t]{2}{*}{ Polychaete P.J.Cribb } & Polystachya elegans Rchb.f & Bristle-like (1-4) \\
\hline & Polystachya seticaulis Rendle & $?$ \\
\hline \multirow[t]{3}{*}{ Polystachya } & Polystachya concreta (Jacq.) Garay \& H.R.Sweet & Moniliform (of various lengths) \\
\hline & Polystachya foliosa (Hook.f.) Rchb.f & Moniliform (of various lengths) \\
\hline & Polystachya tessellata Lindl & Moniliform (of various lengths) \\
\hline \multirow[t]{2}{*}{ Superpositae Kraenzl } & Polystachya eurygnatha Summerh & Clavate $(2-4)$ \\
\hline & Polystachya spatella Kraenzl & Bristle-like (1-3) \\
\hline
\end{tabular}


representatives of Apidae (Melipona sp., Plebeya droryana, Tetragonisca angustula, Trigona spinipes and Paratetrapedia aff. fervida) (Pansarin and Amaral 2006).

Histochemical analyses conducted by Davies et al. (2002) revealed that the main food substance found in the food-hairs of Polystachya was protein. Lipids were invariably absent, whereas starch was often, but not always, detectable. This protein was distributed throughout the cytoplasm and the relative intensity of the xanthoproteic reaction suggested that elevated levels of aromatic amino acids were usually present. Although easily and frequently used for the detection of aromatic amino acids, the xanthoproteic test is not specific for this class of compound, forming a coloured nitroso reaction product with a range of compounds containing an active benzene ring. Consequently, Davies et al. (2002) have recently recommended using the more specific stain Coomassie Blue to test for the presence of protein. According to the xanthoproteic test (Davies et al. 2002), in Polystachya, both atrichotamous labellar epidermal cells and the mucilage secreted onto the adaxial surface of the labellum (e.g. Polystachya campyloglossa Rolfe) were also often rich in protein. Numerous small plastids containing starch were also present in the labellar trichomes of some species (e.g. Polystachya foliosa (Hook.f.) Rchb.f.), whereas in others (e.g. Polystachya pubescens) starch was present in atrichomatous adaxial epidermal cells of the labellum, but it was absent from the trichomes, (Davies et al. 2002). Many angiosperms have flowers that produce fragrance and nutritious, free, powdery pollen. Such flowers, therefore, both attract and are pollinated by pollen-collecting bees (Reis et al. 2004). Thus, the presence of food-hairs and fragrance in Polystachya would indicate a similar pollination strategy.

Labellar trichomes are very common in Polystachya and show a great diversity of form and function. With few exceptions, the first SEM analysis for this genus (Davies et al. 2002), demonstrated that particular types of trichome were ubiquitous, and thus of limited value in taxonomy, as their distribution did not coincide with the classification accepted at the time. Thus, the aim of the present study is to build upon the foundation laid by Davies et al. (2002) and to extend it to include additional species, as well as to study the micromorphology of the gynostemium relative to the latest infrageneric classification of Polystachya proposed by Mytnik-Ejsmont (2011). Comparative studies of this kind would enable further assessment of the potential taxonomic value of these remarkable epidermal structures.

\section{Materials and methods}

Labella and gynostemia of twenty species of Polystachya, representing eight sections occurring in Africa, Madagascar and Central America (Mexico), were examined by means of scanning electron microscopy. The material used in the study, preserved in Kew Mixture (70\% ETOH, 29\% water and $1 \%$ glycerol), was obtained from the collection of the Department of Plant Taxonomy and Nature Conservation at the University of Gdansk, Poland (Table 2). The taxonomy of Polystachya follows that proposed by MytnikEjsmont (2011), and the authorities for plant names follow Brummit and Powell (1992).

Fresh plant material was firstly fixed so as to avoid decomposition and distortion of tissue (Karcz 2009a), and in order to maintain its integrity relative to that of living tissue (Wróbel et al. 2005). This was achieved by using a buffered aqueous solution of two different fixatives, namely $12.5 \%(\mathrm{w} / \mathrm{v})$ paraformaldehyde (PFA) and $2.5 \%(\mathrm{v} / \mathrm{v})$ glutaraldehyde $(\mathrm{GA})$ at $\mathrm{pH}$ 7. Labellar material was fixed at $4{ }^{\circ} \mathrm{C}$ for $24 \mathrm{~h}$. Spirit-preserved material did not require fixation, merely transferring to the next stage. Both fixed and spirit-preserved plant material were then dehydrated using a graded ethanol series (Wrobel et al. 2005) and subjected to conventional critical-point drying using liquid carbon dioxide $\left(\mathrm{CO}_{2}\right)$, as described by Karcz (2009b). The material was subsequently secured to stubs before coating with gold (Karcz 1996). Finally, the specimens were examined using a Philips XL30 (FEI) scanning electron microscope at an accelerating voltage of 5 or $15 \mathrm{kV}$.

\section{Results}

\section{The micromorphology}

The results for labellar trichomes and papillae generally closely resemble those previously reported by Davies et al. (2002), as follows:

- Diversity of form. Apart from multicellular, cylindrical trichomes, few other types are described here.

- Clavate trichomes are the most common and are present in 55\% of the species studied here.

- With few exceptions, those species bearing moniliform trichomes are mainly restricted to sect. Polystachya.

- Pseudopollen is formed by fragmentation of moniliform trichomes or the detachment of trichomes as bicellular units. Here, we also provide, for the first time, evidence of detachment of terminal cells of clavate trichomes.

- Cells of moniliform trichomes contain protein and some starch (with few exceptions not repeated here but will form the basis of a future study).

- Secreted material is often deposited on the labellar surface, and this may form a film that obfuscates labellar topography. 
Table 2 List of species of Polystachya used in this study (the order of the taxa follows the Mytnik-Ejsmont systematic approach to Polystachyinae (2011)

\begin{tabular}{|c|c|c|c|}
\hline Section & Species & Origin & Accession number \\
\hline \multirow[t]{2}{*}{ Calluniflorae Kraenzl } & Polystachya adansoniae Rchb.f & Africa & p-2729 \\
\hline & Polystachya coriscensis Rchb.f & Africa & p-2724 \\
\hline \multirow[t]{2}{*}{ Galeatae Mytnik } & Polystachya galeata Rchb.f & Africa & p-1008 \\
\hline & Polystachya nyanzensis Rendle & Africa & $\mathrm{p}-2728$ \\
\hline \multirow[t]{4}{*}{ Caulescentes Kraenzl } & Polystachya laxiflora Lindl & Africa & p-2361 \\
\hline & Polystachya bennettiana Rchb.f & Africa & 4248 \\
\hline & Polystachya albescens subsp. imbricata (Rolfe) Summerh & Africa & p-2736 \\
\hline & Polystachya thomensis Summerh & Africa & p-1630 \\
\hline \multirow[t]{4}{*}{ Polystachya Hook. } & Polystachya concreta (Jacq.) Garay \& H.R.Sweet & Africa & p-2734 \\
\hline & Polystachya paniculata (Sw.) Rolfe & Africa & 85PTGA378 \\
\hline & Polystachya lineata Rchb.f & Central America & 4226 \\
\hline & Polystachya odorata Lindl & Africa & p-2725 \\
\hline \multirow[t]{2}{*}{ Superpositae Kraenzl } & Polystachya bamendae Szlachetko, Baranow \& Mytnik & Africa & 4227 \\
\hline & Polystachya simplex Rendle & Africa & $\mathrm{p}-2727$ \\
\hline \multirow[t]{2}{*}{ Humiles Summerh } & Polystachya bella Summerh & Africa & $\mathrm{p}-1345$ \\
\hline & Polystachya pubescens (Lindl.) Rchb.f & Madagascar & p-1395 \\
\hline \multirow[t]{3}{*}{ Cultriformes Kraenzl } & Polystachya cultriformis (Thouars) Sprengel & Africa & $\mathrm{p}-1815$ \\
\hline & Polystachya maculata P.J.Cribb & Africa & p-1823 \\
\hline & Polystachya vulcanica Kraenzl & Africa & $\mathrm{p}-1479$ \\
\hline Pseudomonophyllae Mytnik & Polystachya rosea $\mathrm{Ridl}$ & Madagascar & 8871 \\
\hline
\end{tabular}

\section{Classification of epidermal papillae/trichomes}

A great diversity of epidermal structures was present on the labellum and gynostemium of Polystachya. Based on the work of Davies et al. (2002), we recognized two main groups: Papillae (unicellular protuberances of various length that are usually wider at the base) and trichomes (unicellular or multicellular structures of diverse shape, with a narrow point of insertion and often with a differently shaped apex). It must, however, be acknowledged that such classification is largely used for convenience since in many orchids, the morphology of labellar papillae and trichomes often intergrade, and in such cases, trichomes probably develop from papillae. Fourteen different types of papillae/trichomes were found on the labella and gynostemia of the species investigated in the present paper. These are shown below (Figs. 1, 2).

Owing to the varying density of papillae/trichomes on different regions of the labellum, the latter was divided into distinct areas and the relative densities (Fig. 3) of these epidermal structures were recorded diagrammatically for each of the species investigated, as follows (Fig. 4).

Trichomes in Polystachya are generally uniseriate, oneto four-celled, often with differently shaped (subclavate to clavate) terminal cells. The complete range of labellar micromorphology for all studied species of Polystachya is represented in Table 3 and in Fig. 5. Detailed descriptions of each species investigated are presented below according to sections.

\section{Polystachya Hook. sect. Calluniflorae Kraenzl}

\section{Polystachya adansoniae Rchb.f}

The labellar trichomes are cylindrical (Fig. 6a, Online Resource 1a, b) and two- to four-celled; apices often conical and tapering. The trichomes present on the proximal part of the labellum consist of two cells, whereas those occurring on the central part of the labellum consist of two, three or four cells (Online Resource 1c-f). The trichomes are not frequent, but are more densely arranged centrally. The labellum margin lacks trichomes and the labellum lacks obvious papillae.

\section{Polystachya coriscensis Rchb.f}

The labellum is densely clothed with cylindrical trichomes centrally (Fig. 6b, Online Resource 2a), occurring less densely towards the lateral lobes. The trichomes consist of one or two cells (Online Resource 2b, c). The distal part of the labellum (epichile) bears obpyriform to hemispherical papillae (Online Resource 2d). 


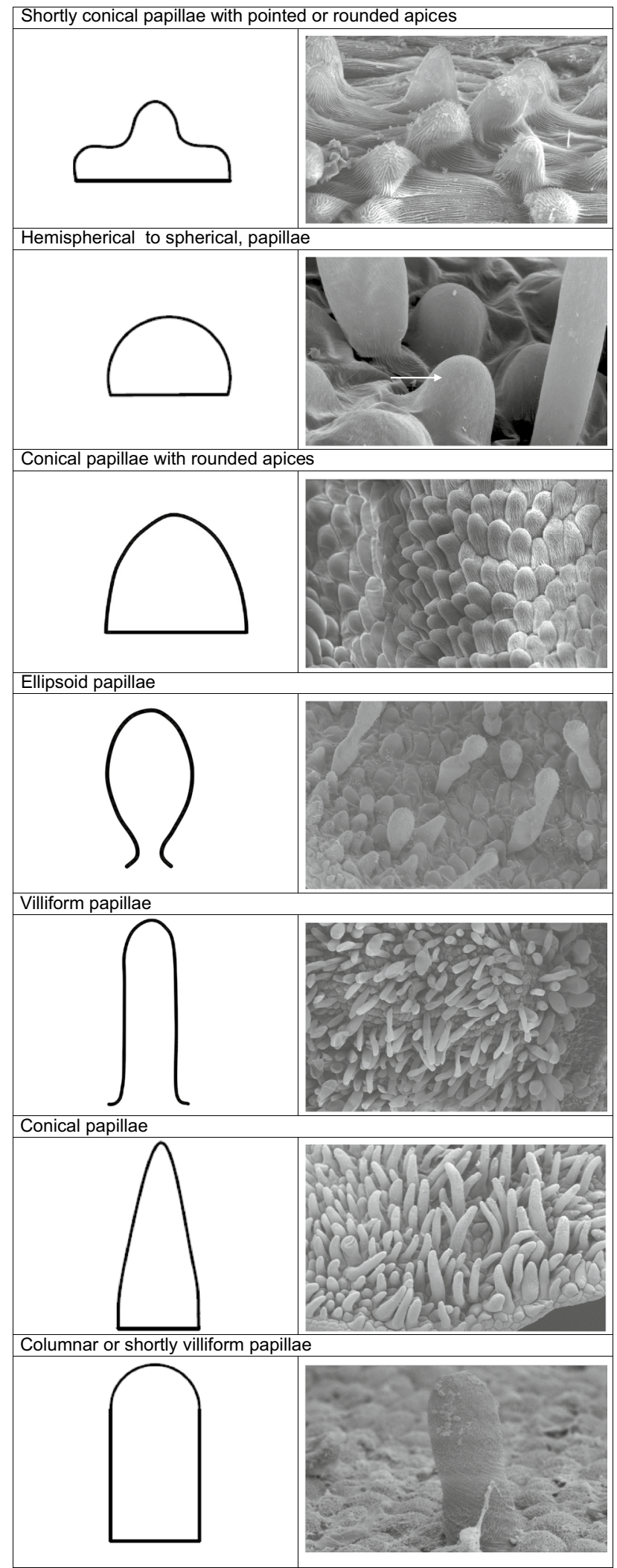

Fig. 1 The types of papillae found on the labella and gynostemia of the Polystachya species investigated in the present paper

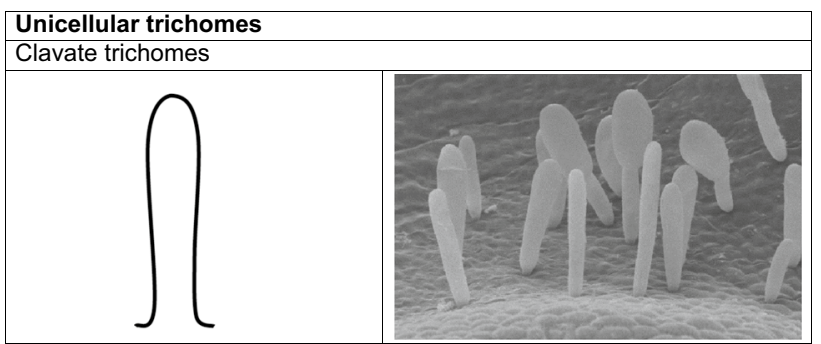

Multicellular trichomes

Cylindrical, multicellular trichome, bristle-like trichome

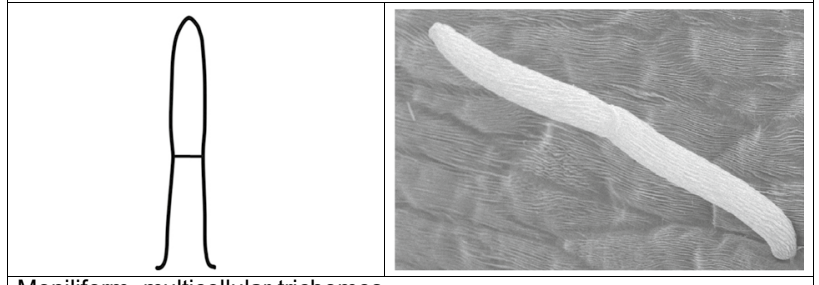

Moniliform, multicellular trichomes

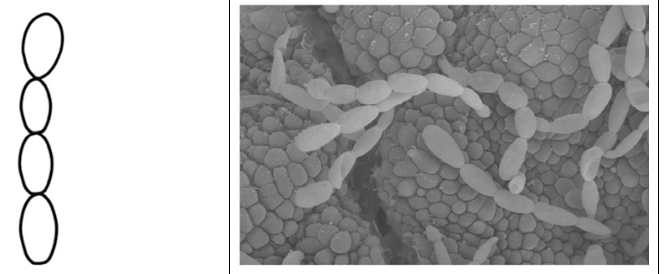

Multicellular trichomes with conical apices

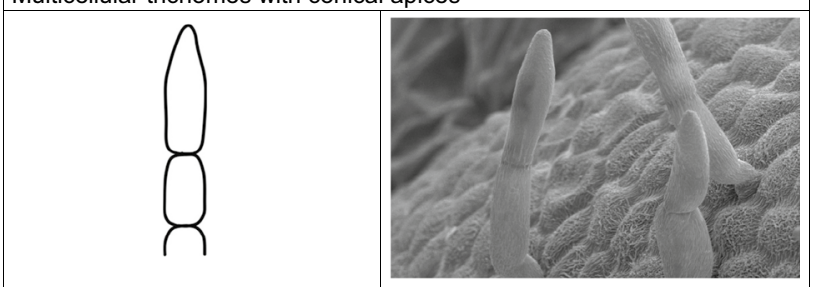

Clavate (club-like) bicellular trichomes

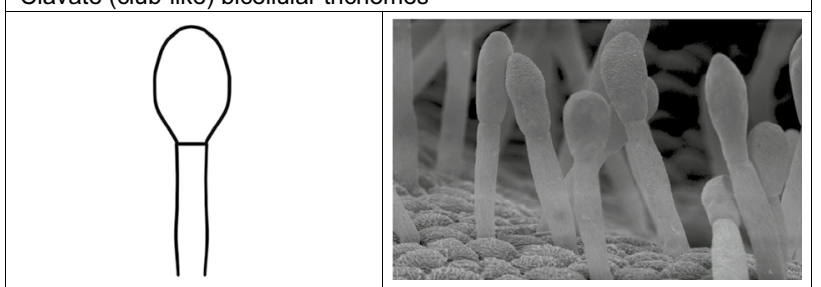

Fig. 2 The types of trichomes found on the labella and gynostemia of the Polystachya species investigated in the present paper

\section{Polystachya Hook. sect. Galeatae Mytnik}

\section{Polystachya galeata Rchb.f}

The labellum is clothed with papillae and multicellular trichomes (Fig. 6c). The trichomes are clavate and comprise two or three cells. Proximally, the central part bears very dense, short, conical papillae (Online Resource 3a, b). Individual, shortly conical papillae with rounded apices occur on the margins of the proximal part of the labellum (Online 
Fig. 3 Relative density of trichomes and papillae on labella and gynostemia of Polystachya

\begin{tabular}{|c|c|c|c|c|}
\hline Degree & Trichomes & Papillae & Characterization & Description as used \\
\hline 4 & $\Delta A$ & & $\begin{array}{l}\text { Density of trichomes/papillae } \\
\text { is so great that their proximal } \\
\text { parts are not visible }\end{array}$ & Very dense \\
\hline 3 & & & $\begin{array}{c}\text { 6-15 trichomes/papillae per } \\
0.01 \mathrm{~mm}^{2}\end{array}$ & Dense \\
\hline 2 & & & $\begin{array}{c}3-5 \text { trichomes/papillae per } \\
0.01 \mathrm{~mm}^{2}\end{array}$ & Rare, small number \\
\hline 1 & & $\therefore$ & $\begin{array}{c}\text { Individual, } 1-2 \\
\text { trichomes/papillae per } 0.01 \\
\mathrm{~mm}^{2}\end{array}$ & Single, individual \\
\hline 0 & & & No trichomes / papillae & $\begin{array}{c}\text { No trichomes / } \\
\text { papillae }\end{array}$ \\
\hline
\end{tabular}

Fig. 4 Terminology for parts of the labellum used in the Results section
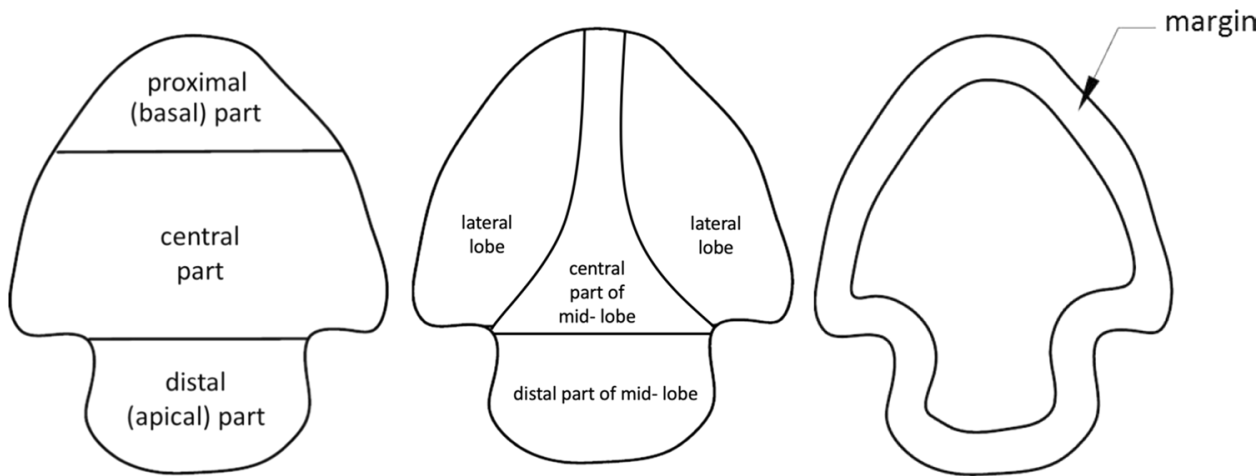

Resource 3c). Margins of the central, fleshy ridge bear very dense obpyriform to hemispherical papillae (Online Resource $3 \mathrm{~d}-\mathrm{f})$. The epichile is also ridged and bears clavate (club-like), 2-3-celled trichomes and very dense conical and obpyriform to hemispherical papillae (Online Resource $3 \mathrm{~g}, \mathrm{~h}$ ). Clavate, two-celled, sparse trichomes occur on the gynostemium (Online Resource 3i, j). Individual papillae occur on the column-foot (Online Resource 3j).

\section{Polystachya nyanzensis Rendle}

The labellum of Polystachya nyanzensis is papillose with sparse, clavate trichomes (Fig. 6d, Online Resource 4a). The proximal trichomes comprise two or three cells (Online Resource 4b-d), whereas those on the central and distal parts of the labellum are two-celled (Online Resource 4e). Many conical, obpyriform and hemispherical papillae occur along the mid-nerve (Online Resource $4 \mathrm{f}, \mathrm{g}$ ). The epichile is rugose. Clavate, two- or three-celled trichomes occur on the column-foot (Online Resource $4 \mathrm{~h}$ ).

\section{Polystachya Hook. sect. Caulescentes Kraenzl}

\section{Polystachya laxiflora Lindl}

The labellum of Polystachya laxiflora is clothed with short, clavate (club-like), two-celled (Fig. 6e, Online Resource 5a-d) trichomes and conical, obpyriform, shortly hemispherical or villiform, unicellular papillae (Online Resource $5 \mathrm{e}-\mathrm{g}$ ). Conical and obpyriform to shortly hemispherical papillae occur proximally (Online Resource 5a). Conical papillae are replaced by villiform papillae on the distal part of the labellum (Online Resource 5f). The gynostemium is clothed with two-celled, cylindrical and clavate trichomes arranged along the lateral margins and at the apex of the column (Online Resource $5 \mathrm{~h}-\mathrm{j}$ ). The dorsal sepal is clothed adaxially with clavate trichomes 
Table 3 Types of labellar structures found in all Polystachya species studied (present results appear in bold, the reminder are those of Davies et al. (2002)

\begin{tabular}{|c|c|c|c|}
\hline Section & Species & Trichome type (number of cells) & Papillae \\
\hline \multirow[t]{3}{*}{ Calluniflorae Kraenzl } & Polystachya adansoniae Rchb.f & Cylindrical (2-4) & \\
\hline & Polystachya coriscensis Rchb.f & Cylindrical (1-2) & Obpyriform to hemispherical \\
\hline & Polystachya woosnami Rendle & Bristle-like (1-4) & \\
\hline \multirow[t]{2}{*}{ Galeatae Mytnik } & Polystachya galeata Rolfe & Clavate (2-3) & $\begin{array}{l}\text { Conical and obpyriform to hemi- } \\
\text { spherical }\end{array}$ \\
\hline & Polystachya nyanzensis Rendle & Clavate (2-3) & $\begin{array}{l}\text { Conical, obpyriform and hemi- } \\
\text { spherical }\end{array}$ \\
\hline \multirow[t]{5}{*}{ Caulescentes Kraenzl } & Polystachya laxiflora Lindl & Clavate (2) & $\begin{array}{l}\text { Conical, obpyriform, shortly hemi- } \\
\text { spherical or villiform, unicellular }\end{array}$ \\
\hline & Polystachya bennettiana Rchb.f & Clavate (2-4) cylindrical (1) & $\begin{array}{l}\text { Obpyriform to hemispherical to } \\
\text { spherical }\end{array}$ \\
\hline & $\begin{array}{l}\text { Polystachya albescens subsp. imbri- } \\
\text { cata (Rolfe) Summerh }\end{array}$ & Clavate (2-4) & hemispherical \\
\hline & Polystachya thomensis Summerh & Moniliform (2-5) & $\begin{array}{l}\text { Villiform, obpyriform to hemi- } \\
\text { spherical to spherical }\end{array}$ \\
\hline & Polystachya caloglossa Rchb.f & Clavate (2-4) & \\
\hline \multicolumn{4}{|l|}{ Polystachya Hook. } \\
\hline & $\begin{array}{l}\text { Polystachya concreta (Jacq.) Garay } \\
\text { \& H.R.Sweet }\end{array}$ & Moniliform (2-6) cylindrical (1-2) & $\begin{array}{l}\text { Obpyriform to hemispherical or } \\
\text { almost spherical }\end{array}$ \\
\hline & Polystachya odorata Lindl & Moniliform & Obpyriform to hemispherical \\
\hline & Polystachya lineata Rchb.f & $\begin{array}{l}\text { Cylindrical (1) moniliform- } \\
\text { clavate (1-5) }\end{array}$ & Obpyriform to hemispherical \\
\hline & Polystachya paniculata (Sw.) Rolfe & Clavate (2) cylindrical (1) & Obpyriform \\
\hline & Polystachya foliosa (Hook.f.) Rchb.f & Moniliform (of various lengths) & \\
\hline & Polystachya tessellata Lindl & moniliform (of various lengths) & \\
\hline \multirow[t]{4}{*}{ Superpositae Kraenzl } & Polystachya simplex Rendle & $\begin{array}{l}\text { Columnar or cylindrical (1) } \\
\text { clavate }(2)\end{array}$ & Obpyriform to hemispherical \\
\hline & $\begin{array}{l}\text { Polystachya bamendae Szlachetko, } \\
\text { Baranow \& Mytnik }\end{array}$ & Clavate (1-2) cylindrical (1) & Villiform, conical and obpyriform \\
\hline & Polystachya eurygnatha Summerh & Clavate (2-4) & \\
\hline & Polystachya spatella Kraenzl & Bristle-like (1-3) & \\
\hline \multirow[t]{6}{*}{ Humiles Summerh } & Polystachya bella Summerh & $\begin{array}{l}\text { Cylindrical and clavate (1) clavate } \\
\text { (2) }\end{array}$ & $\begin{array}{l}\text { Conical, obpyriform, villiform and } \\
\text { hemispherical }\end{array}$ \\
\hline & $\begin{array}{l}\text { Polystachya pubescens (Lindl.) } \\
\text { Rchb.f }\end{array}$ & $\begin{array}{l}\text { Bristle-like but with clavate apices } \\
\text { (1-3) cylindrical (1-3) }\end{array}$ & \\
\hline & Polystachya lawrenceana Kraenzl & Clavate $(2-4)$ & \\
\hline & Polystachya cf. ottoniana Rchb.f & Clavate (2-4) & \\
\hline & Polystachya piersii P.J.Cribb & Clavate (1-2) & \\
\hline & Polystachya aff. villosa Rolfe & Clavate (1) & \\
\hline \multirow[t]{4}{*}{ Cultriformes Kraenzl } & $\begin{array}{l}\text { Polystachya cultriformis (Thouars) } \\
\text { Sprengel }\end{array}$ & Clavate (1-2) & $\begin{array}{l}\text { Conical to obpyriform or hemi- } \\
\text { spherical }\end{array}$ \\
\hline & Polystachya maculata P.J.Cribb & Clavate (2-4) & \\
\hline & Polystachya vulcanica Kraenzl & Absent & $\begin{array}{l}\text { Conical, obpyriform and hemi- } \\
\text { spherical }\end{array}$ \\
\hline & Polystachya campyloglossa Rolfe & Cylindrical (1-3) & \\
\hline Pseudomonophyllae Mytnik & Polystachya rosea $\mathrm{Ridl}$ & Clavate and moniliform (1-5) & $\begin{array}{l}\text { Villiform, hemispherical, conical } \\
\text { and obpyriform }\end{array}$ \\
\hline Polychaete P.J.Cribb & Polystachya elegans Rchb.f & Bristle-like (1-4) & \\
\hline
\end{tabular}


Fig. 5 Sections (including subsections) of Polystachya, showing the types of trichome present

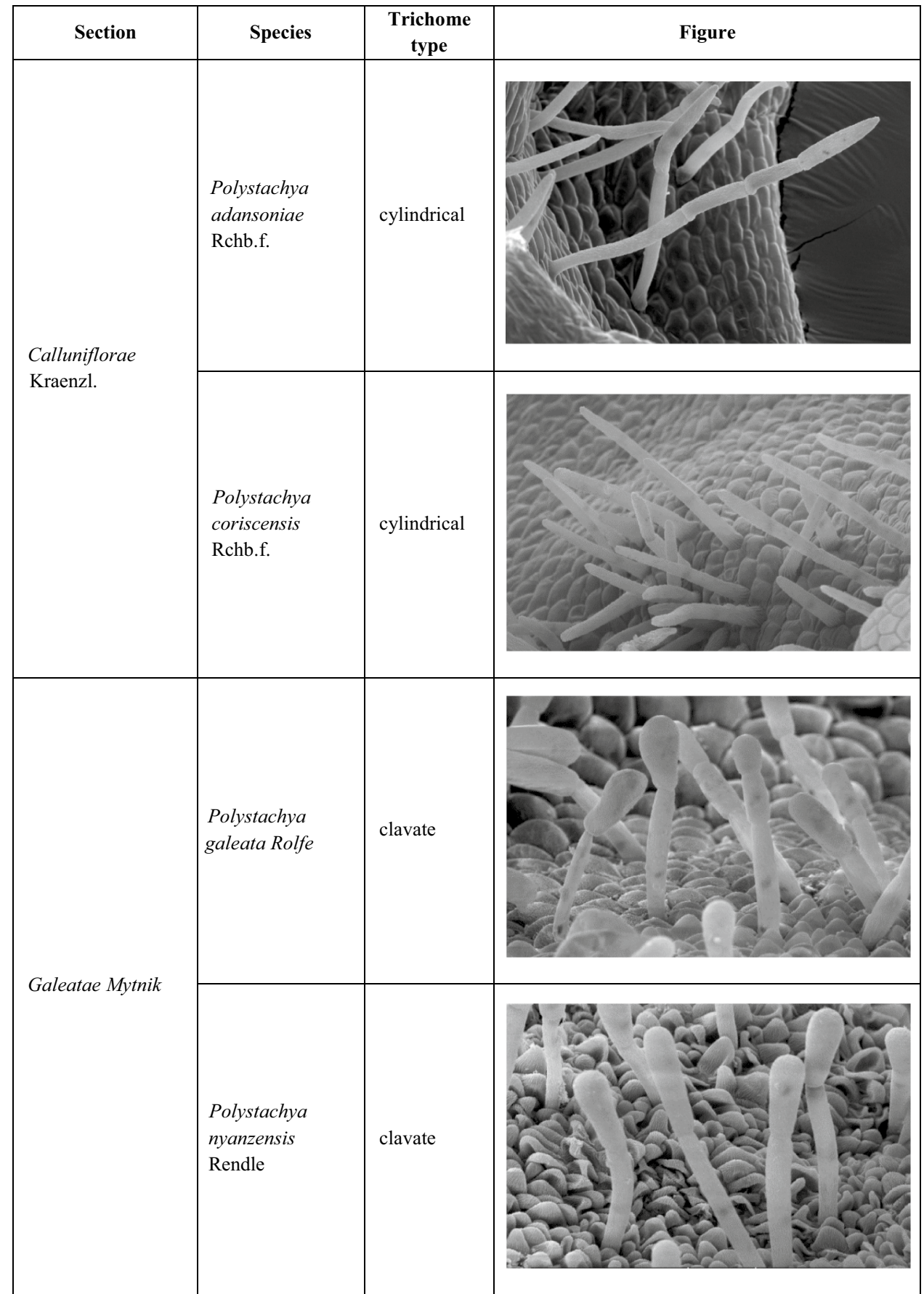

consisting of an elongate stalk cell and an inflated terminal cell, together with conical and hemispherical papillae (Online Resource 5 k).

\section{Polystachya bennettiana Rchb.f}

The labellum of Polystachya bennettiana bears obpyriform to hemispherical to spherical papillae and sparse, cylindrical trichomes (Fig. 6f, Online Resource 6a). The trichomes comprise one or two cells with tapering apices (Online Resource 6b-d). Distally, the labellum is rugose, and the labellar margin glabrous (Online Resource 6e, f). Centrally, residues of secretion were present (Online Resource $6 \mathrm{~g}, \mathrm{~h}$ ). Cells of the labellum are elongate and striate proximally, but more isodiametric and papillose distally. The central part of the column, just beneath the stigma, bears unicellular, cylindrical trichomes (Online Resource 6i, j). 
Fig. 5 (continued)

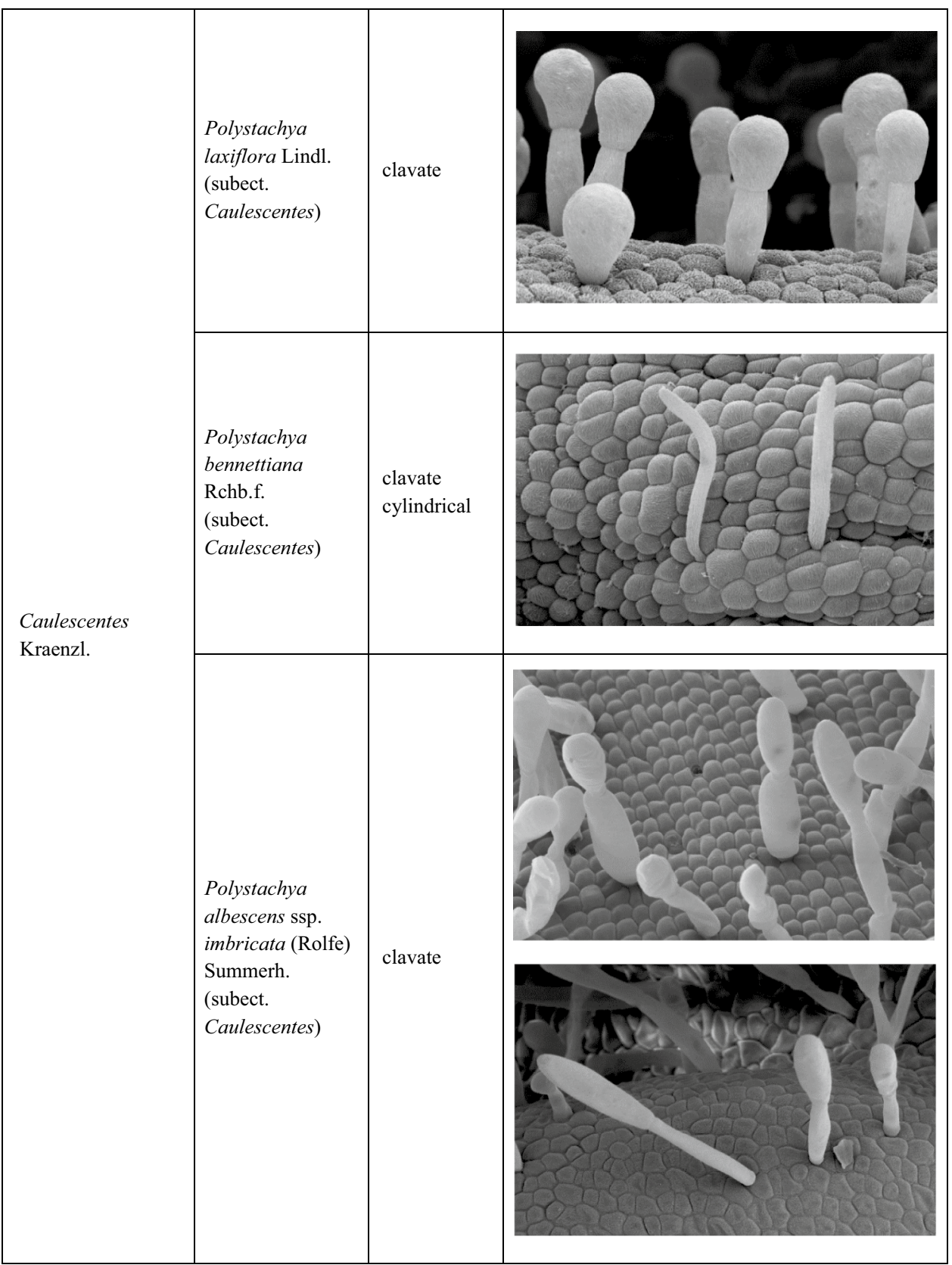

\section{Polystachya albescens subsp. imbricata (Rolfe) Summerh}

The labellum of Polystachya albescens subsp. imbricata is characterised by the presence of 2-4-celled, clavate trichomes and hemispherical papillae (Fig. 6g, Online Resource 7a). Proximally, the trichomes are two- to fourcelled (Online Resource 7b, c), but centrally and distally, two-celled (Online Resource 7e, g). They occur mainly on the margins of the fleshy callus, but are only sparsely distributed on the central part of the callus (Online Resource $7 d)$. Hemispherical papillae occur on the distal part of the labellum (Online Resource 7f). The trichomes are very densely distributed on the epichile, and have rounded terminal cells (Online Resource $7 \mathrm{~g}, \mathrm{~h}$ ). Similar, 2-celled trichomes occur on the column, but their terminal cells tend to have conical bases and more pointed apices (Online Resource 7i-k).

\section{Polystachya thomensis Summerh}

The labellum of Polystachya thomensis is characterised by multicellular, moniliform trichomes (Fig. 6h, Online Resource 
Fig. 5 (continued)

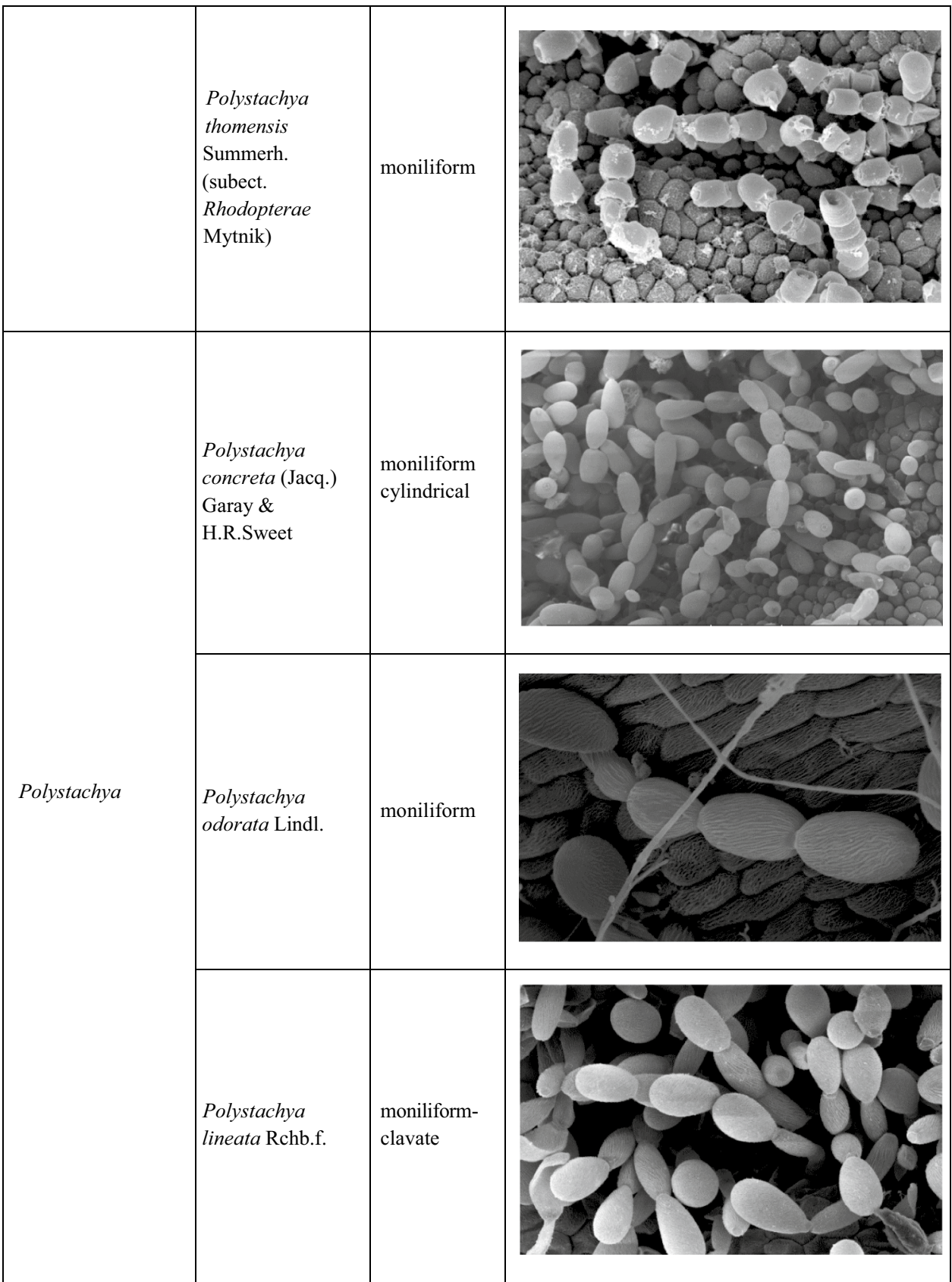

8a, b) comprising spherical to columnar cells (Online Resource $8 \mathrm{c})$. The proximal part of the labellum is very densely clothed with two- to five-celled moniliform trichomes (Online Resource 8d) forming a wide band that recedes centrally (Online Resource 8e). Some trichomes occur on the callus (Online Resource 8f-h) and, together with villiform papillae (Online Resource 8i), densely clothe the margins of the lateral lobes of the labellum and the area beneath the callus (Online Resource $8 \mathrm{~h}$ ). The relative density of trichomes, however, diminishes towards the rugose epichile (Online Resource $8 \mathrm{j}, \mathrm{k}$ ) and the labellar papillae may be obpyriform to hemispherical to almost spherical.

The column-foot bears individual, short trichomes and hemispherical papillae (Online Resource 8 1). 
Fig. 5 (continued)

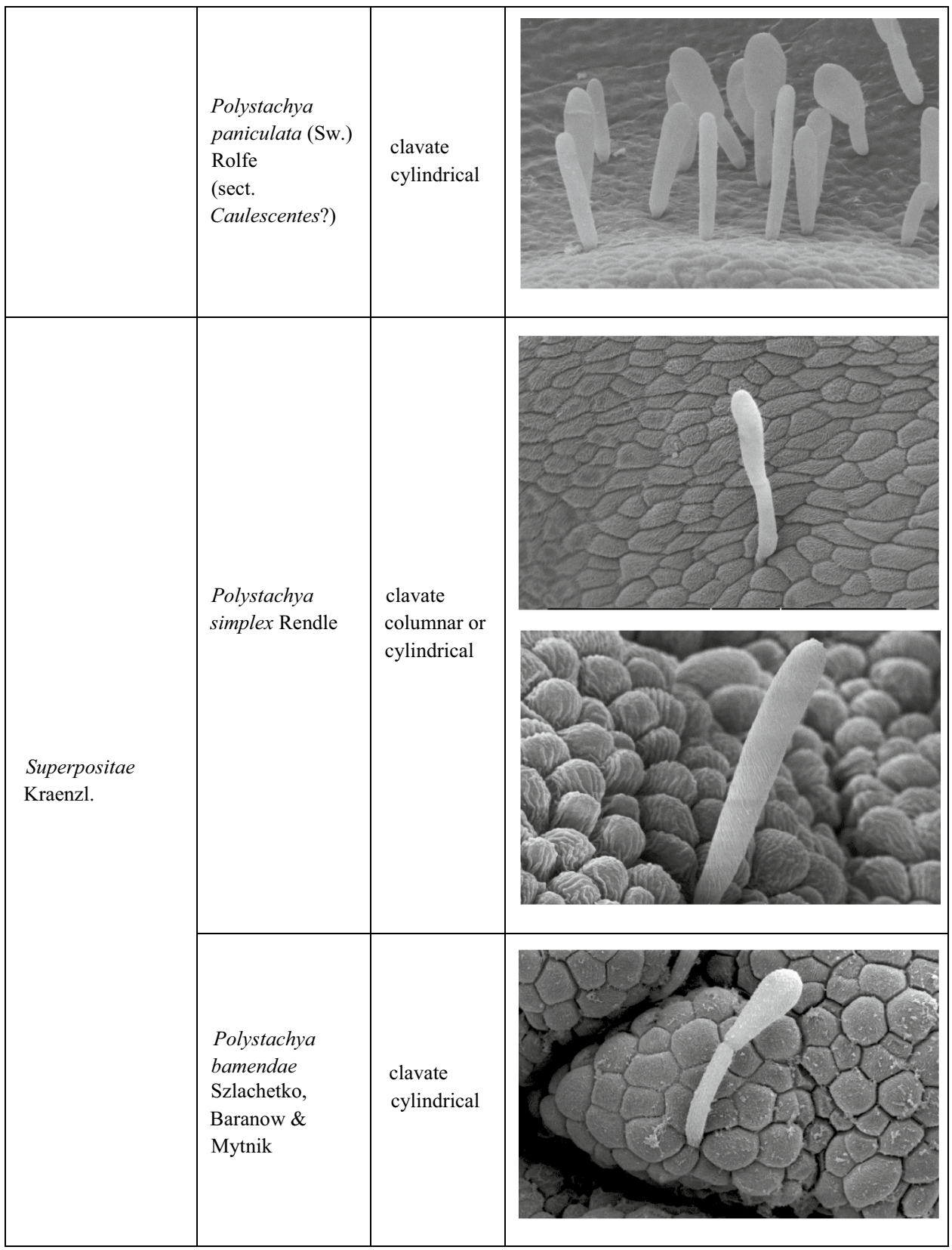

\section{Polystachya Hook. sect. Polystachya}

\section{Polystachya concreta (Jacq.) Garay \& H.R.Sweet}

The labellum of Polystachya concreta bears two types of trichomes (Fig. 6i). Unicellular, cylindrical, striate trichomes (together with occasional bicellular clavate trichomes) occur densely on the proximal part of the labellum (Online Resource 9a-d), whereas small, cylindrical trichomes occur sparsely on the callus (Online Resource 9e, f), and moniliform, two- to six-celled trichomes form a cushion along the fleshy ridge (Online Resource $9 \mathrm{~g}, \mathrm{~h}$ ). The latter is very densely distributed on the central part of the labellum (Online Resource 9i), becoming reduced in number towards the epichile, where they comprise three to seven cells. Here also occur one- to two-celled cylindrical trichomes, papillae tend to be obpyriform to hemispherical or almost spherical (Online Resource 9j-1). 
Fig. 5 (continued)

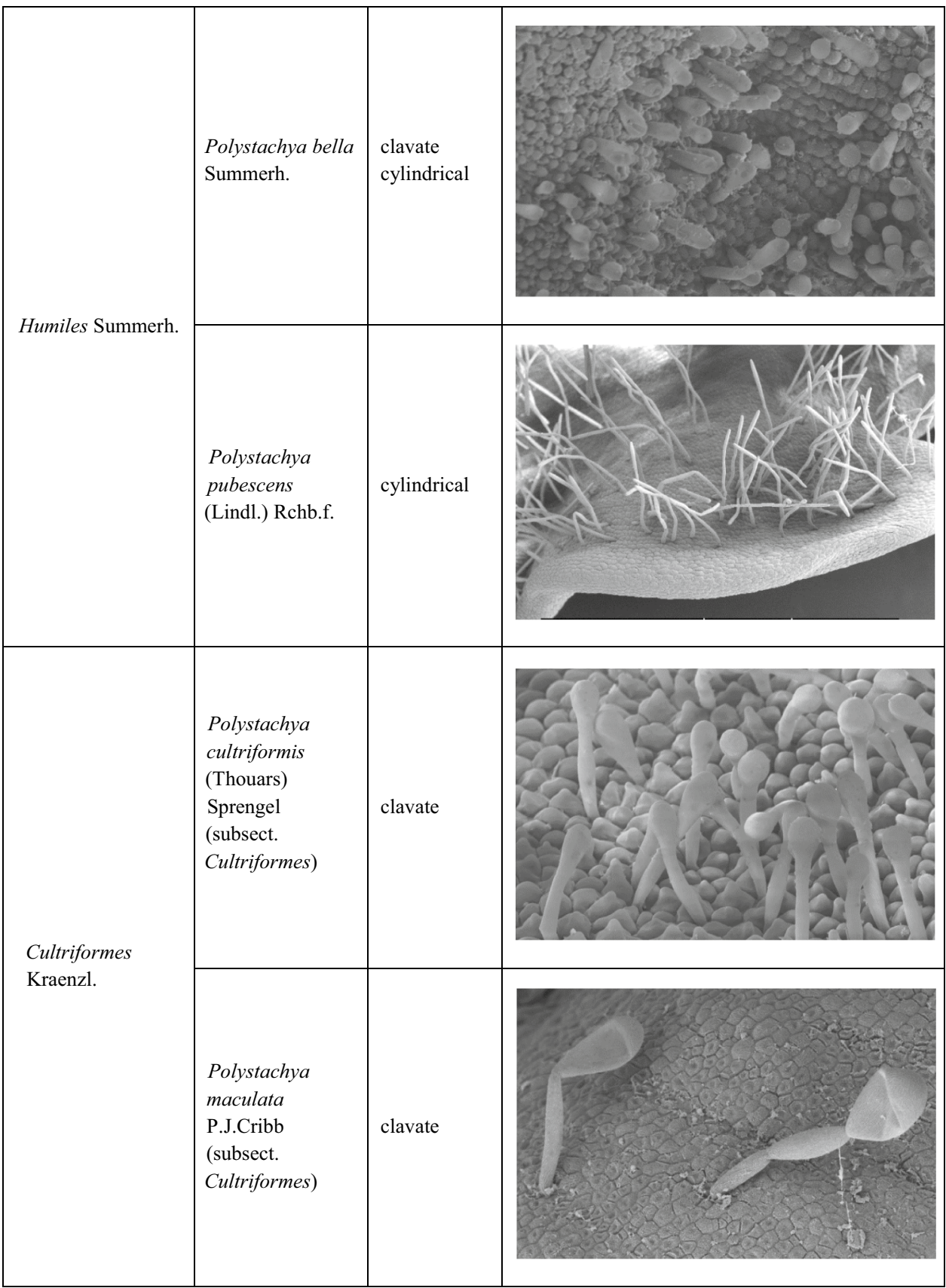

\section{Polystachya odorata Lindl}

The proximal part of the labellum of Polystachya odorata is clothed with shortly moniliform trichomes (Fig. 6j, Online Resource 10a) with a highly striate cuticle (Online Resource 10b, c). In most moniliform trichomes, the terminal cell is inflated (Online Resource 10d, e). No trichomes occur on the callus (Online Resource 10f). Obpyriform to hemispherical papillae are present on the epichile (Online Resource $10 \mathrm{~g}$ ) and these are highly striate (Online Resource 10 h).

\section{Polystachya lineata Rchb.f}

The labellum of Polystachya lineata is characterised by the presence of very dense, unicellular and cylindrical or multicellular, moniliform-clavate trichomes (Fig. 6k, Online Resource $11 \mathrm{a}, \mathrm{b})$. The moniliform-clavate trichomes consist of one to five cells (Online Resource 11c). The basal cells of moniliform trichomes are elongate and stalk-like, and the terminal cells tend to become detached (Online Resource $11 \mathrm{~d}-\mathrm{g}$ ). No trichomes occur on the labellum margins (Online Resource 11a, h), and both the epichile and 
Fig. 5 (continued)

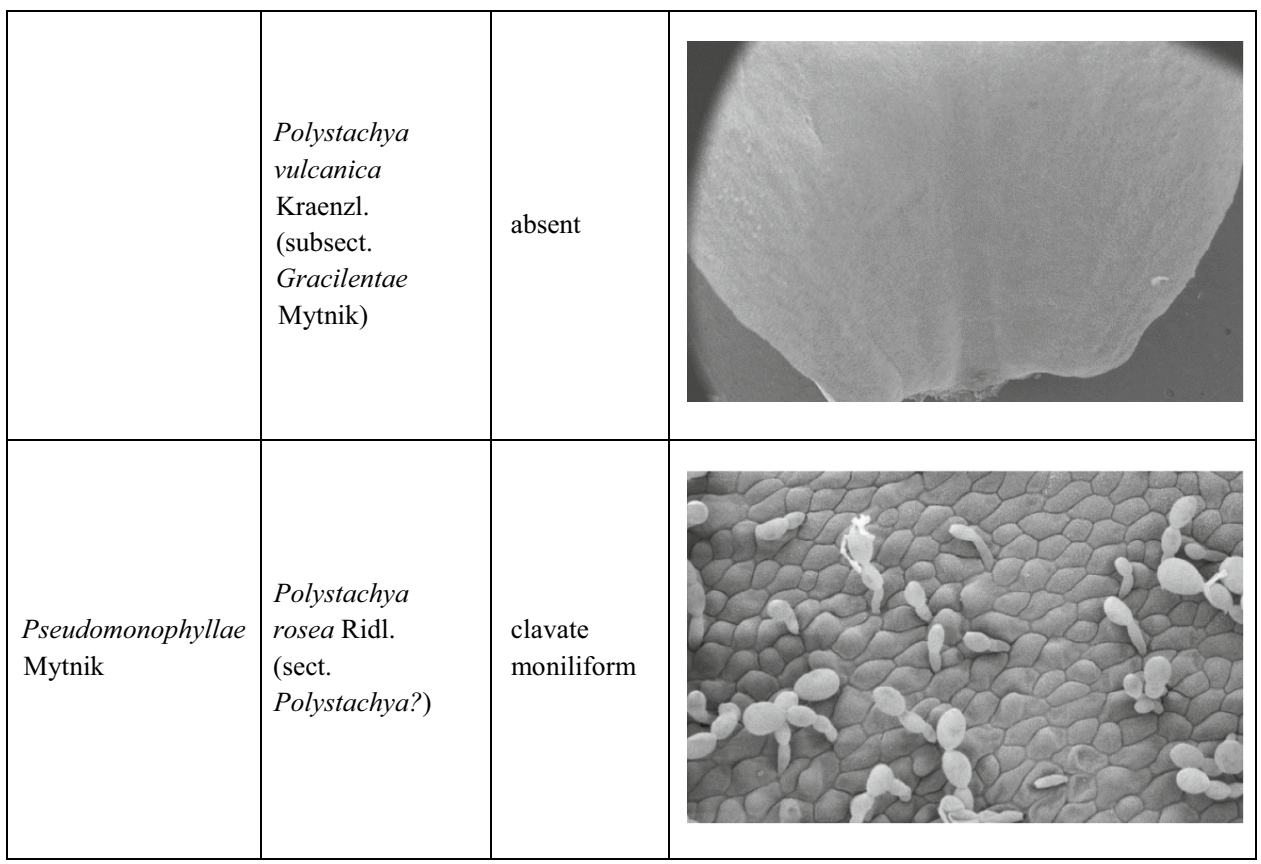

margins comprise obpyriform to hemispherical papillae (Online Resource $11 \mathrm{~h}$ ). The gynostemium is glabrous.

\section{Polystachya paniculata (Sw.) Rolfe}

The labellum of Polystachya paniculata is rarely clothed with unicellular, cylindrical trichomes. Bicellular, clavate trichomes and individual obpyriform papillae both rarely occur only on the proximal part of the labellum (Fig. 61, Online Resource 12a-d). The epidermal cells are slightly convex, isodiametric and have a smooth or slightly striate cuticle (Online Resource 12e). The gynostemium lacks trichomes (Online Resource 12f).

\section{Polystachya Hook. sect. Superpositae Kraenzl}

\section{Polystachya simplex Rendle}

Individual, unicellular, columnar or cylindrical trichomes and bicellular, clavate trichomes occur on the labellum of Polystachya simplex (Fig. 6m, Online Resource 13a). Bicellular, clavate trichomes, are found predominantly on the proximal and central parts of the labellum (Online Resource $13 \mathrm{~b}-\mathrm{d})$. The epichile is rugose and clothed with both types of trichome (Online Resource 13e-g). Atrichomatous cells of the labellar epidermis are isodiametric and slightly convex and striate, whereas the papillae may be obpyriform to hemispherical and striate. Scattered, two-celled, clavate or unicellular, cylindrical trichomes occur on the column-foot (Online Resource $13 \mathrm{~h}$ ), and again, papillae here are both isodiametric and striate.

\section{Polystachya bamendae Szlachetko, Baranow \& Mytnik}

Proximally, the labellum of Polystachya bamendae bears clavate and unicellular or bicellular trichomes (Fig. 6n, Online Resource 14a, b). Individual, clavate trichomes occur scattered on the callus, which is located on the proximal part of the labellum (Online Resource 14c). The central part of the labellum bears a cushion of very dense, unicellular, villiform papillae, whereas the margins bear conical papillae (Online Resource 14d, e). The rugose epichile bears scattered, individual, unicellular, cylindrical trichomes and bicellular, clavate trichomes, as well as conical and obpyriform papillae (Online Resource 14f, g). Residues of secretion or detritus seemingly occur on the labellum (Online Resource $14 \mathrm{~h}$ ). Adaxial epidermal cells of the labellum are generally isodiametric, except on the central part of the callus, where they are elongate (Online Resource 14c). The column-foot is densely clothed with villiform or conical papillae, with pointed or rounded apices and unicellular, cylindrical trichomes (Online Resource 14i-k).

\section{Polystachya Hook. sect. Humiles Summerh}

\section{Polystachya bella Summerh}

The labellum of Polystachya bella is clothed with both papillae and trichomes (Fig. 6o, Online Resource 15a). The former structures occur proximally and are mainly obpyriform (occasionally hemispherical), whereas the trichomes are cylindrical to clavate and 1-celled, or clavate and bicellular 

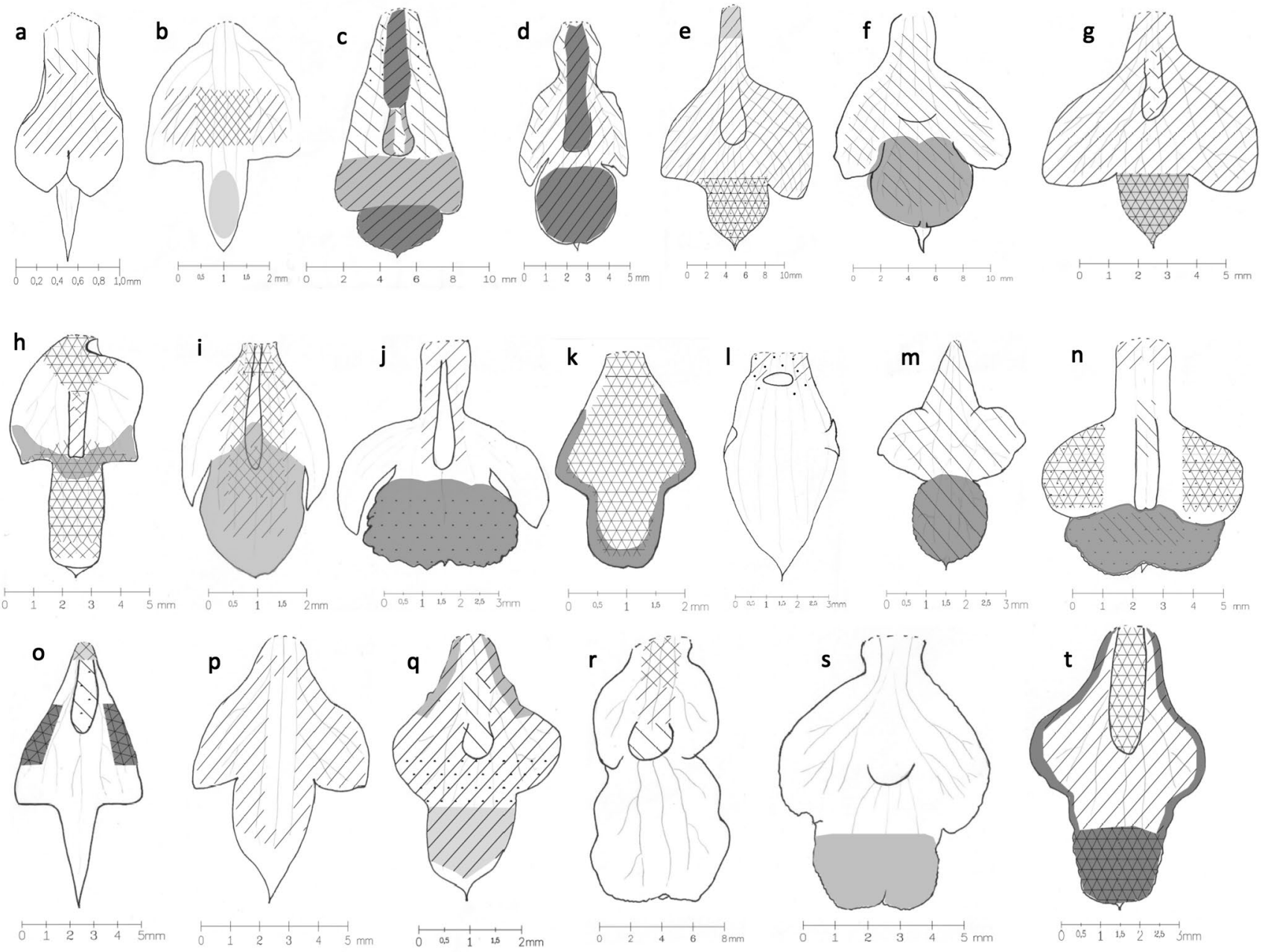

Fig. 6 Relative density of trichomes and papillae on the labellum of Polystachya: a $P$. adansoniae, b $P$. coriscensis, c $P$. galeata, d $P$. nyanzensis, e $P$. laxiflora, $\mathbf{f} P$. bennettiana, $\mathbf{g}$ P. albescens subsp. imbricata, $\mathbf{h} P$. thomensis, $\mathbf{i} P$. concreta, $\mathbf{j} P$. odorata, $\mathbf{k} P$. lineata, $\mathbf{l} P$. paniculata, $\mathbf{m}$ P. simplex, $\mathbf{n}$ P. bamendae, o P. bella, p $P$. pubescens, q $P$. cultriformis, $\mathbf{r} P$. maculata, $\mathbf{s} P$. vulcanica, $\mathbf{t} P$. rosea
(Online Resource 15b). The callus has similar papillae and scattered, clavate trichomes (Online Resource 15c). A film of secreted material coats the callus, partly obfuscating the papillae (Online Resource 15d). The margins of the hypochile bear conical, obpyriform, villiform and hemispherical papillae that also become coated with a film of secreted material (Online Resource 15e-g). The epichile is fleshy, slightly rugose and glabrous (Online Resource $15 \mathrm{~h}$ ). Both trichomes and papillae are moderately striate. The gynostemium is glabrous.

\section{Polystachya pubescens (Lindl.) Rchb.f}

The labellum of Polystachya pubescens bears one type of trichome only and no obvious papillae (Fig. 6p, Online
Resource 16a). Trichomes are present mainly on the lateral lobes, but also extend onto the mid-lobe of the labellum (Online Resource 16a-d). They are one- to three-celled and cylindrical, and often have fusiform terminal cells. (Online Resource 16d). There are no trichomes on the proximal and distal parts of the labellum (Online Resource 16e). Trichomes are also absent from the gynostemium. Individual, cylindrical, unicellular or few-celled trichomes are also present on the adaxial surfaces of petals and lateral sepals (Online Resource 16f-h). 


\section{Polystachya Hook. sect. Cultriformes Kraenzl}

\section{Polystachya cultriformis (Thouars) Sprengel}

The labellum of Polystachya cultriformis is clothed with papillae and clavate trichomes. These trichomes are present over the entire surface of the labellum (Fig. 6q, Online Resource 17a), although those on the callus are rather sparser, often occurring singly (Online Resource 17b). Those present on the proximal and central parts of the labellum consist of one or two cells (Online Resource $17 \mathrm{c}, \mathrm{d})$, whereas trichomes present on the epichile are one-celled (Online Resource 17e, f). A film of secretory residue coats the proximal part of the callus and partly obfuscates the labellar topography (Online Resource $17 \mathrm{~g}$ ).

Papillae are present on the margins of the proximal part of the labellum. They are conical to obpyriform or hemispherical (Online Resource 17 h, i), and occasional columnar trichomes are present. The callus lacks papillae, although they may occur on the central part of the labellum. Conical papillae occur on the epichile (Online Resource 17f). The column bears scant one- to two-celled trichomes, and the epidermal cells are strongly striate (Online Resource $17 \mathrm{j}$ ).

\section{Polystachya maculata P.J.Cribb}

The labellum of Polystachya maculata mainly bears clavate trichomes (Fig. 6r, Online Resource 18a). They are densely distributed on the proximal part of the labellum, but less so on the central part (Online Resource 18a-c). Scattered, clavate or columnar trichomes occur on the callus (Online Resource 18d, e). The trichomes comprise two to four cells, and the terminal cell is inflated (Online Resource 18f). Trichomes are absent from the rugose epichile (Online Resource $18 \mathrm{~g}$ ). The labellum lacks papillae and the epidermal cells are isodiametric and striate (Online Resource $18 \mathrm{~h}$, i). The gynostemium is glabrous.

\section{Polystachya vulcanica Kraenzl}

Polystachya vulcanica has a glabrous labellum. The proximal cells are elongate and faintly striate (Fig. 6s, Online Resource 19a, b). Cells of the central part of the labellum are slightly papillose and similarly striate (Online Resource 19c-e). Conical, obpyriform and hemispherical papillae occur on the epichile (Online Resource 19f, g). The gynostemium is glabrous (Online Resource $19 \mathrm{~h}$ ).
Polystachya Hook. sect. Pseudomonophyllae Mytnik

\section{Polystachya rosea Ridl}

The labellum of Polystachya rosea is densely hirsute (Fig. 6t, Online Resource 20a). Clavate and moniliform, one- to five-celled trichomes are very densely distributed proximally on the labellum, together with villiform papillae (Online Resource 20b, c). Conical and obpyriform papillae are present at the margins of the labellum, together with occasional, shortly villiform papillae (Online Resource 20d). The terminal cells of the clavate trichomes tend to become detached (Online Resource 20e). The callus is very densely clothed with moniliform trichomes. Trichomes on the central part of the labellum and along the callus are moniliform, comprising one to five cells (Online Resource 20f). Moniliform, 1-5-celled trichomes, together with villiform and hemispherical papillae also occur on the epichile, and stages in the transition of papillae to trichomes are visible here (Online Resource $20 \mathrm{~g}, \mathrm{~h}$ ). The column-foot is also papillose, with conical and obpyriform papillae (Online Resource 20i). Individual, two-celled clavate trichomes are scattered along the column-foot (Online Resource 20j) and also occur on the adaxial surface of the petals (Online Resource $20 \mathrm{k}$ ).

\section{Discussion}

As well as confirming previous results, the present investigation extends the work of Davies and colleagues in a number of ways. Firstly, it considers the labellar micromorphology of a further fifteen species. Secondly, it analyses the distribution of these various epidermal structures on the labellar surface and attempts to relate distribution to function. However, perhaps its most important contribution is that for the first time, it is possible to relate the labellar micromorphology of Polystachya to a robust, taxonomic classification (MytnikEjsmont 2011). Although Kraenzlin (1926) had subdivided the genus on morphological grounds into 12 sections, and a further five sections had subsequently been added (Summerhayes 1942, 1947; Brenan 1954; Cribb 1978; Podzorski and Cribb 1979), when Davies et al. (2002) had their work published, still no satisfactory infrageneric classification existed, making it difficult to relate micromorphology to taxonomy in a meaningful way. Since then, a monograph and new classification for Polystachya has been published (Mytnik-Ejsmont 2011), thus providing a useful framework for such comparisons. Each of the eight sections represented is discussed below. 


\section{Polystachya Hook. sect. Calluniflorae Kraenzl}

Three species of this section were examined, namely Polystachya adansoniae and $P$. coriscensis in this study, and $P$. woosnamii by Davies et al. (2002). In all cases, the labella bear multicellular, 1-4-celled, cylindrical trichomes with tapering apices, described by Davies et al. (2002) as 'bristlelike'. These trichomes occur most densely on the central part of the labellum and on the lateral lobes. Despite their similarity, these trichomes may vary in the number of cells they contain, the labellum of $P$. woosnamii also bearing clavate trichomes.

All three species possess similar types of trichome distributed in a similar manner on the labellum, therefore this may have taxonomic value.

\section{Polystachya Hook. sect. Galeatae Mytnik}

Species representing section Galeatae were, until 2011 (Mytnik-Ejsmont 2011), assigned to section Cultriformes (sensu Kraenzlin 1926) owing to their possession of unifoliate stems. Results of molecular analyses (Russell et al. 2010a, b a,b; Mytnik-Ejsmont 2011), however, revealed that section Cultriformes sensu Kraenzlin (1926) is polyphyletic and that the unifoliate shoot is a homoplasious character. Consequently, plants formerly assigned to Cultriformes were placed in three sections, one of which is section Galeatae. Labella of $P$. galeata and $P$. nyanzensis share the same type of labellar papillae and the labella of both species are densely clothed with clavate, $2-3$-celled trichomes. Their gynostemia bear 2-celled, cylindrical trichomes. Since the labellar trichomes of two representatives of each of the sections Galeatae and Cultriformes subsect. Cultriformes (see below) show no significant differences, labellar micromorphology here appears to have little taxonomic value.

\section{Polystachya Hook. sect. Caulescentes Kraenzl}

Four of the five species studied (P. caloglossa, P. bennettiana, $P$. laxiflora and $P$. albescens subsp. imbricata) represent the nominal subsection, whereas $P$. thomensis represents the subsection Rhodopterae Mytnik. Differences in the type of labellar indumentum are visible at the subsectional level, two different types of trichomes are present in the subsections. Labella of representatives of subsection Caulescentes are mainly clothed with clavate, 2-4-celled trichomes, although less dense, cylindrical, unicellular trichomes are sometimes present (P. bennettiana). Proximally, the labellum of $P$. thomensis bears 1-5-celled moniliform trichomes. Hitherto, moniliform trichomes had been recorded only for representatives of section Polystachya (Davies et al. 2002), but are observed here in a representative of another section for the first time.

\section{Polystachya Hook. sect. Polystachya}

Five species of this section were examined, namely, $P$. concreta, P. foliosa (Davies et. al. 2002), P. odorata, $P$. lineata (from Mexico) and $P$. paniculata. The taxonomic position of the latter species is the subject of many discussions among taxonomists, with $P$. paniculata being assigned to the nominal section or to the section Caulescentes based on its set of unique characters. The labella of the first four species, which are undoubtedly members of the nominal section, are densely clothed with moniliform, pseudopollen-forming hairs, whereas the gynostemium is glabrous. These multicellular trichomes are detachable and are likely to be collected by insects (Pansarin and Amaral 2006). Probably, the cylindrical trichomes present on the labellum of $P$. concreta and $P$. lineata represent what remain of moniliform trichomes, following fragmentation. The pollination biology of pseudopollen-producing species is still poorly known. Goss (1977) describing the pollination of $P$. flavescens claims that nectar is lacking when pseudopollen is present. Dressler (1993) suggested that the main system of pollination in Polystachya involves the rewarding of small bees with pseudopollen. Pansarin and Amaral (2006) studied the pollination biology of $P$. concreta and P. foliosa (syn. P. estrellensis) and observed the collection of pseudopollen from the lip of the flowers. However, the occurrence of pseudopollen produced by fragmentation of moniliform hairs appears largely to be restricted to representatives of sections Polystachya (excluding $P$. paniculata), Pseudomonophyllae ( $P$. rosea) and Caulescentes (P. thomensis, see discussion above).

The labellar micromorphology of Polystachya paniculata differs from that of all other representatives of sect. Polystachya investigated to date in that moniliform hairs are lacking, with individual, clavate and cylindrical 1- to 2-celled trichomes scattered throughout the proximal part of the labellum. It is worth noting that hitherto, the taxonomic status of $P$. paniculata has causes problems, with some authors considering it to be a member of sect. Caulescentes (Kraenzlin 1926; Cribb 1984; la Croix and la Croix 1997) and others, a member of section Polystachya (Piers 1968; Mytnik-Ejsmont 2011). The labellar micromorphology of $P$. paniculata are similar to that of members of Caulescentes (clavate, 2-celled), but not the section Polystachya (moniliform). This is interesting and may be worth further taxonomic investigation. Apart from this problematic species, moniliform trichomes are characteristic of members of the nominal section and have taxonomic value. 


\section{Polystachya Hook. sect. Superpositae Kraenzl}

Four species were examined, $P$. eurygnatha, $P$. spatella (Davies et al. 2002), P. simplex and P. bamendae. All the species are characterised by the presence of clavate and cylindrical 1-4 celled trichomes on the labellum. Cylindrical trichomes also occur on the column-foot. In addition, the lateral lobes of the labellum and the epichile of P. bamendae possess villiform papillae.

\section{Polystachya Hook. sect. Humiles Summerh}

Both cylindrical and clavate labellar trichomes were present in representatives of this section. Of the species investigated, $P$. pubescens is characterised by its possession of cylindrical, 1-3 celled trichomes only, and $P$. bella has unicellular, cylindrical or 1-2-celled clavate trichomes. Similarly, $P$. aff. villosa has 1-celled, clavate trichomes, whereas $P$. campyloglossa, $P$. lawrenceana and $P$. cf. ottoniana produce 2-4-celled clavate trichomes. The diversity of trichome structure found in sect. Humiles indicates that labellar micromorphology has limited taxonomic value here.

\section{Polystachya Hook. sect. Cultriformes Kraenzl}

Representatives of two subsections were studied, $P$. cultriformis and $P$. maculata, representing the nominal subsection, and $P$. vulcanica, representing the subsection Gracilentae Mytnik. This study confirmed the presence of clavate, twoto four-celled trichomes on the labella of $P$. cultriformis and P. maculata, as described by Davies et al. (2002). In addition, unique columnar trichomes were observed on the callus of the latter species. Study of the gynostemia revealed the presence of cylindrical 2-celled trichomes. The labellum of $P$. vulcanica, however, differed from that of all the other species studied in that it lacked trichomes and only the epichile was papillose. This may be characteristic of all representatives of this subsection, and therefore, further studies are required to ascertain its taxonomic value. Representatives of both subsections clearly differ: Gracilentae are relatively tall and slender plants lacking a labellar callus, whereas those of subsection Cultriformes are robust plants possessing a labellar callus.

\section{Polystachya Hook. sect. Pseudomonophyllae Mytnik}

Polystachya rosea (endemic to Madagascar, Comoros and Seychelles) is often confused with $P$. concreta (sect. Polystachya), but these species differ in a number of ways, including the shape and size of leaves, flower size, colour and scent, and labellum structure. The first pollination event recorded for this species was that observed by Pettersson and Nilsson (1993). According to these authors, the labellum lacks pseudopollen and pollination occurs as a result of deception achieved by extensive variation in flower colour. Moreover, the absence of any fragrance and pseudopollen is possibly an evolutionary consequence of partial fitness dependence on male bee pollinators. Our results, however, clearly show that pseudopollen is present on the labellum of this species, the latter bearing two types of trichome, clavate and moniliform, and both showing a tendency to fragment (Online Resource 20e). According to the results of phylogenetic studies (Mytnik-Ejsmont 2011), P. rosea is in the same clade of $P$. concreta and other representatives of the nominal section (with moniliform trichomes).

Labellar trichomes play an important role, providing tactile and sometimes olfactory stimuli, as well as containing a range of floral pigments, thereby guiding the pollinator and thus facilitating pollination. Furthermore, papillae are able to concentrate solar energy and provide a sufficiently warm environment on the surface of the flower for optimal insect activity. Conversely, reflection of heat by papillae also helps maintain an optimal temperature, and reflection of light (especially in orchid species possessing a speculum) helps attract potential pollinators, whereas its reflection by epidermal striae helps maintain the 'brightness' of the flower, further aiding the pollination process (Davies et al. 2006). Some labellar papillae and trichomes also contain food materials that both attract and reward pollinators, and thus reinforce pollinator behaviour (Davies and Turner 2004). The presence, diversity and location of such trichomes are also important in plant identification and plant taxonomy (Davis and Heywood 1963). However, caution needs to be exercised when considering such characters, as in some cases, they may have no bearing whatsoever on taxonomy, but simply reflect pollinator specificity and the pollination strategy employed (Davies and Turner 2004). As such, floral micromorphology characters should be used in taxonomy only in conjunction with other more reliable characters. For example, the labella of all members of sect. Polystachya hitherto studied, with the sole exception of $P$. paniculata (a taxonomically problematic species), bear moniliform trichomes, but all are united in their general gross morphology. Therefore, should $P$. paniculata be removed from this section? This poses a taxonomic conundrum since some authors (Kraenzlin 1926; Cribb 1984; La Croix and la Croix 1997) place $P$. paniculata in section Caulescentes (its members are characterised by clustered, reed-like stems), whereas others (Piers 1968; Mytnik-Ejsmont 2011) assign it to section Polystachya on account of its distinctive pseudobulbs. However, $P$. paniculata is a distinct species, even for the nominal section, owing to its flower colour and entire lip, a combination of characters which is perhaps rather unique to the genus as a whole, but in particular to section Polystachya. What is more remarkable is that molecular studies (Mytnik-Ejsmont 
2011) also confirm its unique status. The topology of trees based on Bayesian and parsimony analysis of combined data shows that Polystachya paniculata (together with $P$. steudneri) is not part of the clade representing section Polystachya, but forms an isolated clade sister to other clades (Mytnik-Ejsmont 2011, page 47, the strict consensus of the 108 most parsimonious trees in combined plastid (rpl16$t r n \mathrm{~K}, r p l 16, r p l 32-t r n \mathrm{~L})$ analysis for the subtribe Polystachyinae). Since micromorphology data for the labellum raises further doubts, one is perhaps justified in raising this unique species to sectional rank.

The labella of Polystachya thomensis and P. rosea also possess moniliform hairs and there is sufficient justification for assigning the former species to sect. Caulescentes, based on gross morphology and molecular analyses (Mytnik-Ejsmont 2011, page 42, the trees from the Bayesian and parsimony analyses, clade III). Conversely, the latter species, assigned to section Pseudomonophyllae by Mytnik-Ejsmont (2011) is problematic, since based on the results of molecular analyses (Mytnik-Ejsmont 2011, page 42 , the trees from the Bayesian and parsimony analyses, clade I), it belongs to the same clade as does $P$. concreta and other representatives of the nominal section Polystachya (which also possess moniliform trichomes similar to those present of P.rosea). Therefore, separating species currently assigned to sect. Pseudomonophyllae from those of sect. Polystachya, can no longer perhaps be justified and consequently, further studies on Pseudomonophyllae are needed.

Similarly, Polystachya vulcanica differs from all other species of sect. Cultriformes investigated in that its labellum is entirely devoid of trichomes. However, this species is the only representative of the subsection Gracilentae investigated, the other two species studied representing subsection Cultriformes. Representatives of the former subsection are relatively tall and slender plants lacking a labellar callus, whereas those of the latter are robust plants with a labellar callus. Differences between the labellar micromorphology of $P$. vulcanica and that of members of other species of sect. Cultriformes may also be taxonomically significant at sub-sectional level.

\section{Conclusions}

The study revealed seven types of papillae and five types of trichomes (uni- and multi-cellular) in Polystachya, some of which are described here for the first time. Clavate trichomes are the most common and are present in $60 \%$ of the species studied. Moniliform trichomes mainly occur in the sect. Polystachya and are strongly characteristic of the section. Pseudopollen is formed by fragmentation of moniliform trichomes or the detachment of other trichomes as bicellular units. We also provide, for the first time, an evidence for the detachment of the terminal cells of capitate trichomes.

This study endorses the seminal work of Davies and coworkers (Davies et al. 2002), but also raises some further important questions of its own regarding the infrageneric classification of Polystachya, its pollination and the evolution of its labellar characters. These include: how did the various types of labellar trichome observed here evolve? Can we relate the different types of papillae and trichomes to particular roles? Clearly, when it comes to understanding Polystachya, we have only just scraped the surface.

\section{Compliance with ethical standards}

Conflict of interest The authors declare that they have no conflict of interest.

Human and animal rights This chapter does not contain any studies involving human participants or animals performed by any of the authors.

Informed consent Informed consent was obtained from all individual participants included in the study.

Open Access This article is licensed under a Creative Commons Attribution 4.0 International License, which permits use, sharing, adaptation, distribution and reproduction in any medium or format, as long as you give appropriate credit to the original author(s) and the source, provide a link to the Creative Commons licence, and indicate if changes were made. The images or other third party material in this article are included in the article's Creative Commons licence, unless indicated otherwise in a credit line to the material. If material is not included in the article's Creative Commons licence and your intended use is not permitted by statutory regulation or exceeds the permitted use, you will need to obtain permission directly from the copyright holder. To view a copy of this licence, visit http://creativecommons.org/licenses/by/4.0/.

\section{Information on Electronic Supplementary Mate- rial}

Online Resource 1. Labellum of Polystachya adansoniae, a-b cylindrical, multicellular trichomes on proximal part of labellum, c-f central part of labellum with 2-4-celled trichomes with tapering, pointed apices.

Online Resource 2. Labellum of Polystachya coriscensis, a-c central part with cylindrical 1- to 2-celled trichomes, d obpyriform to hemispherical papillae on the epichile. Note the presence of cuticular striae. Online Resource 3. Labellum and gynostemium of Polystachya galea$t a$, a-b proximal part of labellum with conical papillae and clavate, 2-3-celled trichomes, c proximal part of labellum with developing papillae and a clavate trichome, $\mathbf{d - f}$ central part of the labellum (the ridge), g-h rugose epichile with clavate trichomes and conical and obpyriform to hemispherical papillae, $\mathbf{i}$ the gynostemium with sparse trichomes and papillae, $\mathbf{j}$ the column-foot with individual clavate trichomes and papillae.

Online Resource 4. Labellum and gynostemium of Polystachya nyanzensis, a-d proximal and central part of the labellum with clavate, multicellular trichomes, e-g central and distal part of the labellum with 
conical and obpyriform to hemispherical papillae and two-celled trichomes, $\mathbf{h}$ column-foot with sparse clavate, two-celled trichomes.

Online Resource 5. Labellum, gynostemium and dorsal sepal of Polystachya laxiflora, a-b proximal part of the labellum with conical and obpyriform to shortly hemispherical papillae and 2-celled, clavate trichomes, c-d central part of the labellum with 2-celled, clavate trichomes and obpyriform papillae, e-g distal part of the labellum with clavate trichomes and conical and villiform papillae, $\mathbf{h}-\mathbf{j}$ gynostemium with cylindrical and clavate trichomes, $\mathbf{k}$ adaxial surface of dorsal sepal with, conical papillae and clavate trichomes. Note the cuticular striae (i-j) and that there is some evidence of cuticular blistering and possible secretion on the surface of the terminal cell of certain trichomes (d and i).

Online Resource 6. Labellum and gynostemium of Polystachya bennettiana, a labellum, b-d cylindrical, one- or two-celled trichomes, e-f ridged distal part of labellum with unicellular trichomes and obpyriform to hemispherical or spherical papillae, g-h labellar surface showing residues of secreted material, $\mathbf{i}-\mathbf{j}$ gynostemium with unicellular, cylindrical trichomes beneath the stigma.

Online Resource 7. Labellum and gynostemium of Polystachya albescens subsp. imbricata, a labellum, b-c proximal part of labellum with clavate, 2- to 4-celled trichomes and obpyriform papillae, d-e labellar callus, $\mathbf{f}$ labellum epichile with hemispherical and obpyriform papillae, g-h epichile with trichomes, i-k trichomes on the column with more elongate terminal cells.

Online Resource 8. The labellum and gynostemium of Polystachya thomensis, a labellum, b-e moniliform trichomes (d-e) occur on the proximal part of the labellum, $\mathbf{f}-\mathbf{h}$ detail of the labellar callus, $\mathbf{i}$ callus comprising obpyriform to hemispherical to almost spherical papillae, and margin of lateral lobe of labellum with villiform papillae and moniliform trichomes, $\mathbf{j}-\mathbf{k}$ epichile of labellum with obpyriform to hemispherical papillae and moniliform trichomes, $\mathbf{I}$ column-foot with hemispherical papillae and trichomes with distinct heads.

Online Resource 9. Labellum and adaxial surface of dorsal sepal of Polystachya concreta, $\mathbf{a}$ entire flower, $\mathbf{b}$ labellum, c-d proximal part of the labellum with cylindrical trichomes, e-f callus with cylindrical and capitate trichomes, $\mathbf{g}$-h central part of the labellum with moniliform trichomes along the callus, $\mathbf{j}-\mathbf{l}$ epichile of labellum with moniliform and cylindrical trichomes, together with obpyriform to hemispherical papillae.

Online Resource 10. Labellum of Polystachya odorata, a entire labellum, b-c trichomes, d-e striate moniliform trichomes with inflated terminal cells, $\mathbf{f}$ labellum callus lacking trichomes, $\mathbf{g}$ distal part of the labellum with obpyriform to hemispherical papillae, $\mathbf{h}$ labellar papillae showing cuticular striations.

Online Resource 11. Labellum of Polystachya lineata, a labellum, b-f unicellular, cylindrical trichomes and multicellular trichomes, the latter comprising chains of up to five cells, $\mathbf{g}$ stage in fragmentation of trichome, $\mathbf{h}$ view of central and distal part of labellum.

Online Resource 12. Labellum and gynostemium of Polystachya paniculata, a-d proximal part of the labellum with obpyriform papillae and 2-celled, clavate and unicellular cylindrical trichomes, e epidermal cells of the labellum with smooth cuticle, $\mathbf{f}$ details of glabrous gynostemium.

Online Resource 13. Labellum and gynostemium of Polystachya simplex, a entire labellum, b-d bicellular, clavate trichomes on proximal and central part of the labellum, e-g rugose epichile of labellum with, unicellular, cylindrical trichomes and striate opbyriform, hemispherical or almost spherical papillae, $\mathbf{h}$ column-foot with clavate and cylindrical trichomes.

Online Resource 14. Labellum and gynostemium of Polystachya bamendae, a entire labellum, b proximal part of labellum with clavate trichomes, c callus with scant clavate trichomes, d-e central part of the labellum with conical and villiform papillae, $\mathbf{f}-\mathbf{g}$ epichile with clavate trichomes and conical, obpyriform and villiform papillae, $\mathbf{h}$ residues of secretion or detritus on epichile, i-k column-foot with shortly villiform and conical papillae with pointed or rounded apices.

Online Resource 15. Labellum of Polystachya bella, a entire labellum, b the proximal part of the labellum bears mainly obpyriform papillae together with clavate and cylindrical, trichomes, $\mathbf{c}$ callus with scattered, clavate trichomes and mainly obpyriform papillae, $\mathbf{d}$ callus surface with overlying secretion obfuscating its topography, e-g margin of hypochile with conical, villiform, obpyriform and hemispherical papillae, often with striate cuticle. The overlying film of secreted material is initially deposited between individual cells, $\mathbf{h}$ moderately rugose epichile.

Online Resource 16. Labellum of Polystachya pubescens, a entire labellum. b-d one- to three-celled cylindrical trichomes on labellum margins, $\mathbf{e}$ glabrous epichile of labellum, $\mathbf{f}-\mathbf{g}$ adaxial surface of lateral sepal with unicellular or few-celled, cylindrical trichomes, $\mathbf{h}$ similar trichomes also occur on the petals.

Online Resource 17. Labellum and gynostemium of Polystachya cultriformis, a entire labellum, b callus with bicellular, clavate trichomes, c-d central part of labellum with clavate trichomes, e-f epichile with two-celled trichomes and conical papillae. g proximal part of labellum with film of secretion partly obfuscating topography, $\mathbf{h}-\mathbf{i}$ margin of proximal part of labellum base with conical and obpyriform papillae, and ellipsoid trichomes, $\mathbf{j}$ gynostemium with bicellular trichomes and striate epidermal cells.

Online Resource 18. Labellum of Polystachya maculata, a entire labellum, b proximal part of labellum with multicellular, clavate trichomes, c general view of callus, $\mathbf{d}$ detail of callus with clavate trichomes, $\mathbf{e}$ callus with columnar trichome, $\mathbf{f}$ detail of clavate trichome with inflated terminal cell, $\mathbf{g}$ general view of rugose epichile, $\mathbf{h}$-i atrichomatous cells of labellum with striate cuticle.

Online Resource 19. Labellum of Polystachya vulcanica, a-b proximal part of labellum with elongate cells, c-d central and distal part of labellum with isodiametric cells and obpyriform and hemispherical papillae, $\mathbf{f}-\mathbf{g}$ epichile with obpyriform and conicalpapillae, $\mathbf{h}$ general view of glabrous gynostemium.

Online Resource 20. Labellum, gynostemium and petals of Polystachya rosea, a entire labellum, b-c proximal part of labellum clothed with clavate and moniliform trichomes, $\mathbf{d}$ proximal part of labellum with conical, obpyriform and villiform papillae, e trichomes on proximal part of the labellum showing fragmentation and detachment of terminal cells. Note that such detachment of terminal cells may result in the formation of "unicellular, cylindrical hairs". These, however, can be distinguished from intact cylindrical hairs by their truncated appearance and the flattened outer tangential wall (the original cross-wall of the intact bicellular trichome) with its associated, round scar (point of attachment of terminal cell), $\mathbf{f}$ details of central part of labellum, $\mathbf{g}-\mathbf{h}$ epichile with obpyriform and villiform papillae, together with moniliform trichomes, $\mathbf{i}$ column-foot with conical and obpyriform papillae. j clavate trichome on ventral column surface, $\mathbf{k}$ a similar clavate trichome on adaxial surface of petal.

\section{References}

Arditti J (1992) Fundamentals of orchid biology. Wiley-Interscience, New York

Brenan JPM (1954) Plants collected by the Vernay Nyasaland expedition of 1946. Mem New York Bot Gard 9:1-132

Brummitt RK, Powell CE (1992) Authors of Plant Names: a list of authors of scientific names of plants, with recommended standard forms of their names, including abbreviations. Kew, England

Cribb PJ (1978) Studies in the genus Polystachya (Orchidaceae) in Africa. Kew Bull 32:743-766 
Cribb PJ (1984) Orchidaceae. In: Polhill RM (ed) Flora of tropical East Africa. Balkema, Rotterdam, pp 237-412

Davies KL (2009) Food-hair form and diversification in orchids. In: Kull X, Arditti TJ, Wong SM (eds) Orchid biology: reviews and perspectives. Springer, Berlin, pp 159-184

Davies KL, Roberts DL, Turner MP (2002) Pseudopollen and food-hair diversity in Polystachya Hook. (Orchidaceae). Ann Bot (Oxford) 90:477-484

Davies KL, Stpiczyńska M, Turner MP (2006) A rudimentary labellar speculum in Cymbidium lowianum (Rchb.f.) Rchb.f. and Cymbidium devonianum Paxton (Orchidaceae). Ann Bot (Oxford) 97:975-984

Davies KL, Stpiczynska M, Kaminska M (2013) Dual deceit in pseudopollen-producing Maxillaria s.s. (Orchidaceae: Maxillariinae). Bot J Linn Soc 173:744-763

Davies KL, Turner MP (2004) Morphology of floral papillae in Maxillaria Ruiz and Pav. (Orchidaceae). Ann Bot (Oxford) 93:75-86

Davis PH, Heywood VH (1963) Principles of Angiosperm Taxonomy. Van Nostrand, Princeton

Dodson CH, Frymire GP (1961) Natural pollination of orchids. Missouri Bot Gard Bull 49:133-139

Dodson CH (1962) The importance of pollination in the evolution of the orchids of tropical America. Amer Orchid Soc Bull 31:525-735

Dressler RL (1993) Phylogeny and classification of the orchid family. Timber Press, Portland

Goss GJ (1977) The reproductive biology of the epiphytic orchids of Florida 6. Polystachya flavescens (Lindl.) J.J. Smith Amer Orchid Soc Bull 46:990-994

Janse JM (1886) Imitirte pollenkorner bei Maxillaria sp. Ber Deutsch Bot Ges 4:277-283

Karcz J (2009a) Mikroskopia elektronowa skaningowa w biologii. Uniwersytet Śląski, Katowice

Karcz J (2009b) Etapy przygotowania preparatów do badań w mikroskopie skaningowym. Uniwersytet Śląski, Katowice

Karcz J (1996) Skaningowy mikroskop elektronowy w badaniach karpologicznych. Wiadom Bot 40(3/4):55-65

Kjellsson G, Rasmussen FN (1987) Does the pollination of Dendrobium unicum Seidenf. involve pseudopollen? Orchidee $38: 183-187$

Kraenzlin F (1926) Monographie der Gattung Polystachya Hook. Repert Spec Nov Regni Veg Beih 39:1-136

Krahl AH, Holanda ASS, Krahl DRP, Martucci MEP, Gobbo-Neto L, Webber AC, Pansarin ER (2019) Study of the reproductive biology of an Amazonian Heterotaxis (Orchidaceae) demonstrates the collection of resin-like material by stingless bees. Pl Syst Evol 305:281-291

La Croix IF, la Croix E (1997) African orchids in the wild and in cultivation. Timber Press, Portland

Mytnik-Ejsmont J (2011) A monograph of the subtribe Polystachyinae Schltr. (Orchidaceae). Wydawnictwo Uniwersytetu Gdańskiego, Gdańsk

Pansarin ER, Amaral MCE (2006) Reproductive biology and pollination of two species of Polystachya Hook. in southeastern Brazil: evidence of in Polystachyeae (Orchidaceae). Revista Brasil Bot 29:423-432

Pansarin ER, Amaral MCE (2008) Pollen and nectar as a reward in the basal epidendroid Psilochilus modestus (Orchidaceae: Triphoreae): A study of floral morphology, reproductive biology and pollination strategy. Flora 203:474-483
Pansarin ER, Alves-dos-Santos I, Pansarin LM (2017) Comparative reproductive biology and pollinator specificity among sympatric Gomesa (Orchidaceae: Oncidiinae). Pl Biol 19:147-155. https:// doi.org/10.1111/plb.12525

Pansarin ER, Pansarin LM (2014) Reproductive biology of Epidendrum tridactylum (Orchidaceae: Epidendroideae): a reward-producing species and its deceptive flowers. Pl Syst Evol 300:321328. https://doi.org/10.1007/s00606-013-0884-9

Pansarin ER, da Silva UF, Amaral MCE (2009) Reproductive biology and pollination of southeastern Brazilian Stanhopea Frost ex Hook. (Orchidaceae). Flora 204:238-249. https://doi. org/10.1016/j.flora.2008.01.014

Pansarin ER, Maciel AA (2017) Evolution of pollination systems involving edible trichomes in orchids. AoB PLANTS. https://doi. org/10.1093/aobpla/plx033

Pettersson B, Nilsson LA (1993) Floral variation and deceit pollination in Polystachya rosea (Orchidaceae) on an inselberg in Madagascar. Opera Bot 121:237-245

Piers F (1968) Orchids of East Africa, 2nd edn. Cramer, Lehre

Podzorski AC, Cribb PJ (1979) A revision of Polystachya sect. Cultriformes (Orchidaceae). Kew Bull 34:147-186

Reis MG, Pansarin ER, da Silva UF, Amaral MCE, Marsaioli AJ (2004) Pollinator attraction devices (floral fragrances) of some Brazilian orchids. Arkivoc 6:103-111

Russell A, Samuel R, Rupp B, Barfuss MHJ, Safran M, Besendorfer V, Chase MW (2010) Phylogenetics and cytology of a pantropical orchid genus Polystachya (Polystachyinae, Vandeae, Orchidaceae): evidence from plastid DNA sequence data. Taxon 59:389-404

Russell A, Samuel R, Klejna V, Barfuss MHJ, Rupp B, Chase MW (2010) Reticulate evolution in diploid and tetraploid species of Polystachya (Orchidaceae) as shown by plastid DNA sequences and low-copy nuclear genes. Ann Bot (Oxford) 106:37-56

Stpiczyńska M, Davies KL, Kamińska M (2015) Diverse labellar secretions in African Bulbophyllum (Orchidaceae: Bulbophyllinae) sections Ptiloglossum, Oreonastes and Megaclinium. Bot J Linn Soc 179:266-287

Stpiczyńska M, Płachno BJ, Davies KL (2018) Nectar and oleiferous trichomes as floral attractants in Bulbophyllum saltatorium Lindl. (Orchidaceae). Protoplasma 255:565-574

Summerhayes VS (1942) African Orchids: XII. Bot Mus Leafl 10:257-299

Summerhayes VS (1947) African orchids: XVII. Kew Bull 2:123-133

Van der Cingel NA (2001) An atlas of orchid pollination: America, Africa, Asia and Australia. A.A Balkema Publishers, Rotterdam

Van der Pijl L, Dodson CH (1969) Orchid flowers: their pollination and evolution. University of Miami Press, Coral Gables

Vogel S (1978) Evolutionary shifts from reward to deception in pollen flowers. In: Richards AJ (ed) The pollination of flower by insects, linnean society symposium series. Academic Press, London, pp 89-96

Wróbel B, Zienkiewicz K, Smoliński D, Niedojadło J, Świdziński M (2005) Podstawy mikroskopii elektronowej. Skrypt dla studentów biologii, Uniwersytet Mikołaja Kopernika, Toruń

Publisher's Note Springer Nature remains neutral with regard to jurisdictional claims in published maps and institutional affiliations. 